\title{
How Global Stock Markets Became Infected?* The Coincidence of Interbank Lending and the US Mortgage Market
}

\author{
Christian N. Witt ${ }^{ \pm}$ \\ University of Regensburg
}

\author{
Steffen P. Sebastian \\ University of Regensburg
}

First Version: November 10, 2010

This Version: December 16, 2010

\begin{abstract}
:
We analyze how global stock market contagion has been provoked by banking instability, adverse shocks on the US mortgage market and stock market uncertainty during the subprime financial crisis. In this respect, the interbank market has been a major channel to propagate the crises across assets and countries. Beyond, we find, that measures aiming at a stabilization of global banks have been most likely to prevent the crises from further spreading. Thus, we primarily seek to assist policy makers and market participants in their effort to review the success of rescue actions.
\end{abstract}

Keywords: Banking instability, contagion, financial crises, money market, mortgage, stock market uncertainty

EFM: $\quad 570,780$

\footnotetext{
* We benefited from comments from Gianluca Marcato, Till Strohsal, Christian Waeltermann and Enzo Weber and workshop participants at the Centre for European Economic Research (ZEW), Mannheim.

${ }^{ \pm}$University of Regensburg, Department of Economics, IRE|BS and Center of Finance, Regensburg, phone: +49-941- 943-5084, e-mail: christian.witt@irebs.de

*University of Regensburg, Department of Economics, IRE|BS and Center of Finance, Regensburg, Centre for European Economic Research (ZEW), Mannheim, phone: +49-941-943-5084, e-mail: steffen.sebastian@irebs.de
} 


\section{Introduction}

Since the outbreak of the subprime financial crisis in mid 2007 various actions have been put in place by market participants, governments and central banks to foreclose or at least mitigate the global propagation of 'contagious' shocks in financial markets. Therefore, we seek to review some of these rescue measures. In particular, we study the short-term dynamics of several financial risk factors and how they have spread adverse shocks to global stock markets.

Our analysis yields, that indeed most policy actions in that time have been adequate to limit financial contagion in the short-run. Note, that at this stage we do not provide any evidence regarding their long-term effects. Furthermore, we find, that money market risk premia have channeled adverse shocks from the US mortgage market to global stock markets. Ergo, we show, how the recent crisis has spilled over to real economies across the globe, whereas existing research mostly focuses on the collapse of international money markets, i.e. Brunnermeier (2009), Taylor \& Williams (2009) and Kacperczyk \& Schnabl (2010).

Hence, we examine, if the rescue strategies of policy makers during the recent crisis have been justified and successful in containing a further crisis spread. Still, few research examines those hypothesis empirically (Duca et al. (2010), although policy makers across the globe have claimed to protect their home economies from stumbling international banks. In fact, our study indicates that their short-run stabilization has been necessary to mitigate stock market contagion and prevent real economies from negative repercussions. That is, a higher investment risk for banks caused by stock market contagion would probably induce them to curtail lending in response. In this regard, real economies would ultimately be harmed. ${ }^{1}$ Moreover, stress in the US mortgage market has significantly contributed to bank instability.

\footnotetext{
${ }^{1}$ Stock markets have initially seemed to be uninvolved by financial turmoil and even skyrocketed to all-time highs, though money markets have already deteriorated. De facto, the S\&P 500 lost some $18.2 \%$ until July 1 , 2008 after hitting its all-time high on October 7, 2007 (FTSE: -18.0\%, DAX: -12.1\%, Nikkei: -14.3\%, SMI: $-11.2 \%$; on a total return basis).
} 
Thus, with the benefit of hindsight, those massive government interventions into the economic system might be theoretically motivated from a short-run perspective.

To study stock market contagion and its external factors during the financial crisis, we focus on structural changes in the dynamics of time-varying stock market correlations. For this purpose, we analyze the USD money market, the US mortgage market and stocks markets for 18 industrialized countries. First, we estimate time-varying stock market correlations visà-vis the S\&P 500 through DCC-GARCH models (Engle \& Sheppard, 2001) to prevent potential biases, e.g. heteroscedasticity, common-cause interdependence or structural misspecifications, as argued in Forbes \& Rigobon (2002) and Corsetti et al. (2005). Second, contagion is identified by comparing the average levels of these correlations during the crises with the full sample period. Third, by applying a VAR model to stock market correlations for a pre-crisis and crisis period, we examine the influence of external factors. We are therefore able to relate stock market contagion to its presumed sources and channels.

The remainder of the paper is structured as follows. In section 2 we will shortly summarize major contagion channels, before illustrating our empirical hypothesis in section 3 . Thereafter, section 4 describes the employed data, while we conduct our empirical analysis in section 5. Finally, section 6 concludes.

\section{Contagion}

Since the seminal book on financial crisis written by Kindleberger (1978), a widespread literature on financial contagion has developed, which by now is far too extensive, to be shortly summarized here. However, Dornbusch et al. (2000), Pritsker (2001), Kaminsky et al. (2003) and recently Reinhart \& Rogoff (2009) provide comprehensive surveys on the theoretical and empirical research conducted in this field. Thus, we limit ourselves to concisely describe the fundamental dynamics and sources for financial contagion, which have 
been developed to explain the repeatedly observed cross-market shock propagations in the course of financial crisis.

In this respect we follow a working definition of financial contagion, where crossmarket correlations significant increase after a shock has hit one financial market. It has been evolved by Mishkin (1991), Baig \& Goldfein (1999), Dornbusch et al. (2000), Forbes \& Rigobon (2002), Kaminsky et al. (2003), Bae et al. (2003). That is, negative shocks in one market have unusual strong adverse effects on other markets in times of financial turmoil, thereby passing on the 'crisis virus'. Apart from that, three channels for the spreading of financial contagion have been identified so far - the correlated information channel, liquidity channel and risk channel.

First, the correlated-information channel describes a situation, where shocks to one market bare new information, which is also important for other markets. Therefore, negative innovations might directly or indirectly spread to other markets. However, research has mostly concentrated on price changes as the original information shock. For instance, Dornbusch, et al. (2000) and van Rijckeghem \& Weder (2001) describe the correlatedinformation channel for direct trade links between countries. Meanwhile Kiyotaki and Moore (2002) focus on balance-sheet losses due to asset price declines, which cause a drop in net worth for all other firms holding the same asset. In contrast, Diamond \& Dybvig (1983) more generally show that contagion in the banking system can be provoked as an extreme case of multiple equilibria, once the arrival of new information leads to the rational expectation of an imminent insolvency of a bank. In that case, all investors would withdraw their entire deposits at the same time, thereby forcing the entire banking system to collapse.

Second, the liquidity channel terms a mechanism, where a shock to one financial market translates into a liquidity shortage of all other financial markets, which may finally affect both investor behavior and asset prices. In particular, investors become forced to reallocate funds 
to prevail their own financial health, thereby forwarding the original shock to other market participants. For example, the model of Allen \& Gale (2000) demonstrates how the withdrawal of interbank deposit holdings leaves banks vulnerable to unexpected high liquidity shocks and urges them to asset fire-sales. Similarly, Kodres \& Pritsker (2002) emphasize portfolio rebalancing across markets as another source for sustained downward pressure of asset prices due to initial negative price movements. This effect also holds for financial derivatives, as pointed out by Garber (1998) and Dodd (2000). However, as Brunnermeier \& Pedersen (2008) argue, an agent's losses in one market may reduce his funding ability, finally leading to a further disposal of assets. Indeed, Longstaff (2010) finds that falling asset prices have considerably influenced funding liquidity during the subprime financial crisis.

Third, with regard to the risk channel, a shock to one market's risk premium reduces an investor's willingness to take over risk elsewhere. Consequently, shifts in one risk premium might explain return movements in other asset markets, since their risk premium adjusts in response. For instance, the models of Vayanos (2004) and Acharya \& Pedersen (2005) exhibit, how innovations to the liquidity risk premium of a particular asset might translate into changes of the entire economy's risk premium. Besides, Taylor \& Williams find evidence, that an increase in counterparty risk of banks contributed to rising money market risk premia between mid 2007 and mid 2008 (prior to Lehman Brothers insolvency).

\section{How Stock Markets Became Infected?}

In this section we outline, why the US mortgage market, money market risk premia and stock market uncertainty might induce stock market contagion and how they interact. In fact, our notion is that money market risk premia - counterparty risk and liquidity risk - have propagated adverse shocks towards global stock markets, which have rooted in the US mortgage market. 
Our point is, that different from traditional asset pricing (Sharpe (1964), Lintner (1965), debt financing is risky and therefore drives the expected rate of return of a leveraged investor. As a consequence, a diverse set of debt related risk premia potentially affects asset pricing. Above all, those same factors have brought most money markets around the globe about to deteriorate or even collapse during the subprime crisis. Thus, interbank lending forms an important potential cause or channel for contagion across countries, assets or both.

For the same reason, we focus on unsecured short-term interbank lending, where counterparty risk and liquidity risk are the pre-dominant risk factors. That is, inflation, tax issues and collateralization all play a negligible role due to the market's short maturity. Thus, the observed risk premium is merely up to either banking stability or market conditions. The first one reflects counterparty risk - a borrower's default probability and loss given default and the second one liquidity risk - the availability of credit of any volume at any time at the given interest rate. ${ }^{2}$

However, we argue, that the US mortgage market might have indirectly driven stock market correlations via those two money market risk premia or stock market uncertainty. First, the stability of the international banking sector depends on their exposure to the MBS market, as outlined by Allen \& Carletti (2008) and Kacperczyk \& Schnabl (2010). Hence, a substantial decline in MBS prices induces equity write-downs and rising counterparty risk of banks. Second, negative shocks on the MBS market would constrain the liquidity creation of banks via asset-based lending. Yet, the supply of unsecured lending might not be sufficient as a substitute: The higher banks depend on MBS as a refinancing source, the higher is the potential liquidity risk, as more generally explained by Kiyotaki and Moore (2002). So far, academia is ambiguous about the two points: While Taylor \& Williams (2009) and Eichengreen et al. (2009) identify counterparty risk as the driving factor, Brunnermeier (2009) and Longstaff (2010) plead in favor of liquidity risk. Third, a deterioration of the MBS market

\footnotetext{
${ }^{2}$ Earlier research has focused on illiquidity of the same asset; see Vayanos (2004), Acharya \& Pedersen (2005)
} 
could raise doubts about US economic progress due to its high dependence on the real estate sector. Then, stock market uncertainty raises, based on a weakening mortgage market. In either case, the MBS market forms a potential source for infecting global stock markets.

For our empirical work follows, that the US mortgage market could have indirectly provoked global stock market contagion, while either counterparty risk, liquidity risk or stock market uncertainty might have acted as independent sources or intermediaries. An analysis of correlation dynamics will uncover, whether the influence of external factors has changed. In this respect, a direct impact of the MBS market, money market risk premia or stock market uncertainty exhibits the involvement of the correlated information channel. This is due to the revelation of new information regarding the condition of each market or its participants. In contrast, any indirect interaction between these variables reveals, that a certain combination of risk factors impacts the conduct of investors. Then, the risk channel plays a role.

\section{Data}

We collect data for our subsequent empirical study ranging from January 1, 2004 to September 1, 2009 on a daily basis. Beyond, we split up our sample into a pre-crisis and crisis period to obtain unbiased empirical results, see Forbes \& Rigobon (2002) and Chiang et al. (2007). In line with Kacperczyk \& Schnabl (2010) we choose July 31, 2007 as the first day of the subprime financial crisis. That day the investment bank Bear Stearns already liquidated two sponsored hedge-funds, which had heavily invested into MBS. Ultimately, the market dried up on August 9, when it was "no longer possible to value fairly the underlying US ABS assets" (BNP Paribas, 2007). By contrast, we choose the end of the subprime financial crisis as September 1, 2009, because it allows us to separate from the European sovereign debt crisis, which markets became particularly aware of the same month.

First, we take stock market index data for 19 industrialized countries from Thomson Reuters Datastream and convert them into USD. The data includes indices for the United 
States (S\&P 500), Australia (ASX), Belgium (BSE), Canada (TSX), Denmark (CSE), Finland (HSE), France (CAC), Germany (DAX), Ireland (ISE), Italy (MIB), Japan (Nikkei), New Zealand (NZX), Norway (OSE), Portugal (POPSI), Spain (IBEX), Sweden (SSE), Switzerland (SMI), the Netherlands (AEX) and United Kingdom (FTSE). All indices are computed on a total-return basis by the index provider or otherwise Datastream. We then calculate their daily logarithmic returns. Since trading in Australia, Japan and New Zealand finishes, before the US stock market has even opened, we shift back these market returns for one period. This procedure allows us to examine the US stock market as the origin of the subprime financial crisis, leading those of the other countries, when it comes to processing new information.

Second, we employ the Barclays U.S. MBS performance index as a proxy for the US mortgage securitization market and calculate its logarithmic returns. ${ }^{3}$ Since its launch in 1976, the index has been continuously expanded, while the MBS market has evolved as well. For instance, beginning in April 2007, the index has also covered hybrid adjustable rate mortgages (ARMs). Today, the index is traded at the Chicago Mercantile Exchange.

Third, we obtain data on unsecured USD money market lending, to clearly decompose the implied risk premia. Therein, we follow a method suggested by the Bank of England (2007). In particular, we use interest yields and risk premia with a 12-month maturity, since our counterparty risk measure is not publicly available on a shorter time horizon. In a first step, we derive the money market risk premium by subtracting the risk-free overnight index swap (OIS) rate from the risky LIBOR rate. In a second step, we compute our measure for counterparty risk (CDS), by averaging individual 1-year CDS spreads for 15 banks of the USD LIBOR panel. ${ }^{4}$ Then, we determine the liquidity risk premium (LIQ) as a residual from the money market risk premium.

\footnotetext{
${ }^{3}$ From January 1, 1976 until September 14, 2008 the index had been calculated by Lehman Brothers ("Lehman U.S. MBS Index"). However, no appropriate sub-index exists for the performance of RMBS or CMBS.

${ }^{4}$ Though the LIBOR panel consists of 16 banks, CDS spreads for Royal Bank of Canada are not available.
} 
Fourth, we consider the S\&P 500 volatility index (VIX) as a measure for stock market uncertainty. By the same token, we regard it as a stock market premium to equity investors. Accordingly, we include risk measures for both debt and equity markets. Today, the index trades at the Chicago Board Options Exchange and is calculated as a weighted average from the implied volatility of a range of 30-days-time-to-maturity-options on the S\&P 500.

[Table I]

[Figure 1]

Table [I] depicts descriptive stats for the collected data together with several test statistics on stationarity (ADF), normality (Jarque-Bera) and autocorrelation of ordinary and squared observations (Ljung-Box: $\mathrm{LBQ} / \mathrm{LBQ}^{2}$ ). With respect to the results of the ADF test, we take first differences for the CDS and LIQ time series. Moreover, the Jarque-Bera test statistics indicate a leptokurtic distribution for all series, in virtue of excess kurtosis. Beyond, the evidence from the Ljung-Box tests suggests latent autocorrelation in both first and second moments, because the respective statistics are highly significant at the $1 \%$ level up to order 10 and 20. Visual inspection of the time series affirms the typical volatility clustering of financial time series data (Mandelbrot, 1963), see Figure [1]. In particular, volatility of all stock markets gradually increases, after the S\&P Case-Shiller index ultimately peaks in 2007. Yet, it finally culminates in the months following the collapse of Lehman Brothers on September $15,2008$.

\section{Empirical Study}

We follow a three-step strategy to validate our hypothesis from section 3 . First, we estimate time-varying correlations between the S\&P 500 and the stock markets of 18 industrialized countries. Second, we examine these correlations for structural regime shifts 
after the beginning of financial turmoil on July 30, 2007. Third, we analyze the impact of external factors on the correlation dynamics for the pre-crisis and crisis period.

\section{Estimation of Dynamic Conditional Correlations}

First, we model dynamic conditional correlations (DCC) based on a two-step generalized autoregressive conditional heteroscedasticity (GARCH) estimation approach, which was introduced by Engle (2002) and Engle \& Sheppard (2001). In its standard specification, the model assumes a stationary return process $r_{t}$, where the $\mathrm{k} x 1$ vector of variable values is conditional multivariate normally distributed.

$$
r_{t} \mid I_{t-1} \sim N\left(0, H_{t}\right)
$$

Moreover, the return process is conditional on an information vector I available at $\mathrm{t}-1$. However, $\mathrm{H}_{\mathrm{t}}$ denotes the $\mathrm{k} \mathrm{x} \mathrm{k}$ conditional covariance matrix,

$$
H_{t}=D_{t} R_{t} D_{t}
$$

Here, $\mathrm{R}_{\mathrm{t}}$ depicts the $\mathrm{k} x \mathrm{k}$ time-varying correlation matrix and $\mathrm{D}_{\mathrm{t}}$ the $\mathrm{k} \mathrm{x} \mathrm{k}$ diagonal matrix of time-varying standardized residuals. Residuals are taken from the return process and normalized on time-varying variances derived from univariate GARCH estimates.

As shown by Engle (2002) the likelihood estimator can be divided into a volatility component and a correlation component.

$$
\begin{aligned}
L=- & \frac{1}{2} \sum_{t=1}^{T}\left\{k \log (2 \pi)+2 \log \left(\left|D_{t}\right|\right)\right. \\
& \left.+\log \left(\left|R_{t}\right|\right)+\varepsilon_{t}^{\prime} R_{t}^{-1} \epsilon_{t}\right\}
\end{aligned}
$$

In the first step, only the volatility component is maximized by a univariate (GARCH) model. Given the standardized residual matrix $D_{t}$ of step one the correlation component is then maximized to determine the DCC parameters, $\alpha$ and $\beta$. The typical non-negativity and stationarity assumptions of variances and $\sum_{m=1}^{M} \alpha_{m}+\sum_{n=1}^{N} \beta \leq 0$ are imposed.

$$
R_{t}=\left(1-\sum_{m=1}^{M} \alpha_{m}-\sum_{n=1}^{N} \beta_{n}\right) \bar{R}+\sum_{m=1}^{M} \alpha_{m} \epsilon_{t-m} \varepsilon_{t-m}^{\prime}+\sum_{n=1}^{N} \beta R_{t-n},
$$


For $\alpha=\beta=0$, the conditional correlation $R_{t}$ becomes constant, since it reduces to $\bar{R}$. In either case, the model provides more modeling flexibility reflecting the weakened presumption of constant interlinkage.

When put into practice, the return dynamic specification differs from that standard, to capture each market's individual data generating process. Therefore, we estimate an autoregressive process (AR) of the Box-Jenkins type (1994) with a maximal lag length up to order five, where the Hannan-Quinn information criterion determines the initial specification:

$$
y_{t}=a+\sum_{i=1}^{P} \varphi_{i} y_{t-i}+\epsilon_{t}
$$

Thereafter, lags parameters are recurrently excluded until all are significant, starting with the last one. Thus, the procedure ensures a parsimonious model calibration.

Subsequently, conditional variances are determined employing the standard univariate GARCH model of Bollerslev (1986) with $\mathrm{P}=\mathrm{Q}=1$ lag:

$$
h_{t}=b+\sum_{i=1}^{Q} \omega_{i} h_{t-i}+\sum_{i=1}^{P} \theta_{i} \varepsilon_{t-i}^{2}
$$

Given the time-varying variances, the DCC parameters are then estimated as illustrated in equation (4) with $\mathrm{M}=\mathrm{N}=1$. Hence, we presume the same lag structure for both the volatility and correlation component.

\section{[Table II]}

[Figure 2]

Our estimation results for each step are shown in Table [II]. These include correlations between the S\&P 500 and those of the 18 stock markets, as well as the MBS vis-à-vis counterparty risk (CDS), liquidity risk (LIQ) and stock market uncertainty (VIX). The latter three are later needed to simulate the intensity of indirect shock propagation originating in the US mortgage market. In particular, all variables do not follow any autoregressive process, except for the S\&P 500, CAC, Nikkei, CDS and VIX series. Meanwhile, all GARCH 
parameters are significant at the 5\% significance level, demonstrating that variances are heteroscedastic. Hence, to determine correlations the DCC-GARCH model should be preferred over static methods, which require homoscedasticity. In fact, for all correlation estimates time-dependence can be confirmed, since most DCC parameters easily achieve the $1 \%$ significance level. Moreover, their estimation process is stationary.

In Figure [2] time-varying stock market correlations are depicted for the period April 1, 2004 and September 1, 2009. However, some 65 observations for the period January 1, 2004 to March 31, 2004 are excluded due to model calibration. However, we detect a distinct pattern for European and Asian/Oceanian stock markets. For instance, most European correlations explicitly rise from mid 2007, before gradually falling until mid 2008. From there, correlations jump-start to their peaks and remain on that extraordinary high level. In contrast, the Asian/Oceanian stock market correlations seem to stay more stable, though they face several hikes during the crisis period as well. Only the NZX correlation shows a tendency to decrease, after hitting its crisis peak following the Lehman-Brothers collapse.

\section{Stock Market Contagion during the subprime Financial Crisis}

Second, we identify widespread stock market contagion by comparing the means of their dynamic conditional correlations during the crisis and whole sample period with a $t$-test. Hence, the procedure allows us to derive an intuitive contagion measure, while circumventing pitfalls of more traditional approaches. Most notably, such methodologies compare unconditional correlation coefficients for both periods. However, they are usually biased, because misspecifications of the data generating process and heteroscedasticity are ignored; see Forbes \& Rigobon (2002) and Corsetti et al. (2005). In contrast, our methodology dismantles both caveats by initially specifying the evolution of first and second moments for each variable. Only then, time-varying correlations are determined, after being standardized on heteroscedastic variances. Therefore, our t-test analysis is statistically unbiased, while comparing correlation levels intuitively connects to contagion. 
Moreover, we exclusively focus on stock market correlations vis-à-vis the original crisis country to avoid potential common-cause interdependence. That is, an extraordinary increase in correlations is not erroneously considered as contagion, although both variables are essentially driven by an omitted third factor. ${ }^{5}$ Therefore, we regard the US stock market as the country of origin of the recent financial crisis. For the same reason, we exclude the European Debt Crisis, because the source for contagion must not shift over time. As said before, we also expel some observations for model calibration purposes. Hence, we eliminate any foreseeable bias from common-cause interdependence.

\section{[Table III]}

Our results in Table [III] clearly demonstrate the widespread existence of financial contagion on global stock markets. That is, we find a general increase of correlations vis-à-vis the S\&P 500 for a broad range of stock markets. Thus, our results yield, that financial contagion has not been limited to debt markets. Thereby, it suggests, that the US economy has infected those of other major countries, since stock markets largely reflect expectations on real economic conditions; see Pritsker (2001). Furthermore, correlation levels significantly rise during the crisis for all but one country, while the median increase exceeds $10 \%$. In contrast, we diagnose flight-to-quality (FTQ) due to a significant correlation decrease only once, for the NZX. Taken together, the analysis provides substantial statistical evidence for the contagious infection of global stock markets in the course of the subprime financial crisis.

\section{Identifying Sources and Channels for Infecting Stock Markets}

Third, our analysis of external influences on stock market correlations yields, that mainly two factors have provoked stock market contagion during the recent financial crisis shocks on the mortgage market and stock market uncertainty. In either case, counterparty risk of international banks has functioned as an intermediary for that to happen. That result builds

\footnotetext{
${ }^{5}$ For a more detailed discussion on common factors, see Forbes \& Rigobon (2002).
} 
on the comparison of a vector autoregressive (VAR) model for the tranquil and turmoil period, which clearly reveals these structural changes of short-run dynamics.

For our application a VAR type model allows for a greater modeling flexibility of potential interactions between correlations as well as the influence of external factors. ${ }^{6}$ Hence, we slightly generalize the model framework of earlier studies, to also permit existing lead-lag relations among stock markets; see Chiang et al. (2007). Thus, the model derives as

$$
Y_{t}=\vartheta+\sum_{i=1}^{I} A_{i} Y_{t-i}+\sum_{j=1}^{J} B_{j} X_{t-j}+\epsilon_{t}
$$

Here, $\mathrm{Y}_{\mathrm{t}-\mathrm{i}}$ is a $\mathrm{k} \mathrm{x} 1$ vector of dynamic correlations and $\mathrm{X}_{\mathrm{t}-\mathrm{j}}$ a $\mathrm{k} \mathrm{x} 1$ vector of external factors at time $t$, whereas $A_{i}$ and $B_{j}$ describe $k x k$ matrices of respective factor loadings. Thus, no mutual dependence is assumed among the external factors. The indices $\mathrm{i}$ and $\mathrm{j}$ denote the number of lags. In fact, we choose $\mathrm{I}=\mathrm{J}=1$, corresponding to the data generating process assumed under the DCC-GARCH model.

To distinguish among direct and indirect shocks on stock market correlations, we successively introduce a set of variables, including interaction terms and simulated shocks. In a first regression, the set comprises the four variables CDS, LIQ, VIX and MBS. Hence, the vector $\mathrm{X}_{\mathrm{t}-\mathrm{j}}$ of external factors in equation (7) is defined as

$$
X_{t-j}=M B S_{t-j}+C D S_{t-j}+L I Q_{t-j}+V I X_{t-j}
$$

For the second regression, three interaction terms formed of the CDS, LIQ and VIX variables extend the previous set, to quantify non-linear effects of simultaneously rising risk premia:

$$
\begin{aligned}
X_{t-j}= & M B S_{t-j}+C D S_{t-j}+L I Q_{t-j}+V I X_{t-j} \\
& +C D S_{t-j} * L I Q_{t-j}+C D S_{t-j} * V I X_{t-j}+L I Q_{t-j} * V I X_{t-j} .
\end{aligned}
$$

\footnotetext{
${ }^{6}$ Some research has directly included external factors into the DCC-GARCH estimation process to measure their effect on correlations; see Kim \& Kim (2010). However, these studies have considered only a small number of variables. Meanwhile, the estimation process appeared to be quite unstable and therefore useless for our application, once we experimented with a higher quantity of factors.
} 
For the third regression, we introduce three variables linking the indirect effect of the US mortgage market to certain shock propagation channels. For that purpose, first, time-varying betas for mortgage market shocks directed on counterparty risk, liquidity risk and stock market uncertainty are determined. Second, these betas are shocked with the actual MBS innovations to simulate their effect on those risk premia. Third, we connect shock propagation and transmission channel by multiplying their simulated effect and respective risk premium. The newly created variables are denoted MBS_CDS, MBS_LIQ and MBS_VIX:

$$
\begin{aligned}
X_{t-j}= & M B S_{t-j}+C D S_{t-j}+L I Q_{t-j}+V I X_{t-j} \\
& +C D S_{t-j} * L I Q_{t-j}+C D S_{t-j} * V I X_{t-j}+L I Q_{t-j} * V I X_{t-j} \\
& +M B S_{-} C D S_{t-j}+M B S_{-} L I Q_{t-j}+M B S_{-} V I X_{t-j} .
\end{aligned}
$$

Therefore, our estimation strategy allows us to relate structural changes in correlation dynamics to direct and indirect shock propagation before and after the subprime financial crisis has started.

[Table IV]

Our empirical results in Table [IV] for equations (8) to (10) show, that the influence of direct factors is much more pronounced in the tranquil period, while it shifts towards indirect shock propagation during the crisis. ${ }^{7}$ Moreover, the average model fit considerably increases, though the number of relevant external factors diminishes in the turmoil period. Finally, rising constant values indicate a higher persistence of stock market correlations, after the crisis has begun - in line with our prior detection of global stock market contagion.

In detail, during the tranquil period external factors mostly pass shocks directly on to stock market correlations. This widely holds for the counterparty and liquidity risk variable, and sometimes for stock market uncertainty as well. Note this is usually not the case for the

\footnotetext{
${ }^{7}$ We do not exhibit any parameter values or test statistics for inter-correlation dynamics, since it is irrelevant with regard to the impact of external factors and implications. However, we find a certain lead-lag relation between stock market correlations of bigger and smaller financial centers, which we trace back to altered investors risk perception.
} 
MBS variable. Apart from that, indirect shock propagation involving several risk factors is of less importance, if any it includes liquidity risk. Therefore, money market liquidity risk seems of major relevance to stock market correlations prior to the recent financial crisis. From our point of view, it highlights the reliance of equity investments on short-term lending preceding the crisis.

In contrast, our analysis reveals several changes following the 'credit crunch' of July 2007. First and foremost, indirect shock propagation primarily takes over the role of direct shock propagation. In almost every case, both stock market uncertainty and mortgage market shocks affect stock market correlations, when combined with counterparty risk. Thus, rising banking sector instability seems to be a necessary condition for stock market contagion. ${ }^{8}$ Most notably, in the only case of FTQ, the effect still is significant, but changes signs. Second, as a direct influence only stock market uncertainty plays a role. However, it usually decreases or even disappears, as soon as the above two indirect factors are added to the regressions. Third, many regression constants considerably rise in value during the crisis, thereby indicating a higher persistence of stock market correlation dynamics. That is, a higher unconditional correlation level, which corresponds to our previous findings.

Finally, the additional statistics jointly confirm a high adequacy and robustness of the regression specifications. This is displayed by consistently high F-statistics and rising adjusted $\mathrm{R}^{2}$-statistics, once further external regressors are included. In fact, the average statistic level is higher in the crisis period, with only few exceptions (IBEX, ASX, NZX). The median PUR statistic also clearly increases from $6.21 \%$ to $9.53 \%{ }^{9}$ Moreover, our results remain robust for several alternative specifications. These include alterations of the crisis breakpoint, the examination of correlation changes instead of levels and using residuals of

\footnotetext{
${ }^{8}$ Since only major global banks are included in the USD LIBOR panel, the counterparty risk to some extent informs how investors perceive the (in-)stability of the international banking sector.

${ }^{9}$ The PUR statistic measures, how the model fitness improves due to the inclusion of external regressors compared to a benchmark model. Because we produce unusual high adj. $\mathrm{R}^{2}$ per construction, it is a more appropriate statistic: PUR $=\left(\bar{R}_{\text {Modified }}^{2}-\bar{R}_{\text {Benchmark }}^{2}\right) /\left(1-\bar{R}_{\text {Benchmark }}^{2}\right)$
} 
auxiliary regressions, which exclude additional factors. As a result, our empirical results seem unbiased by misspecifications.

\section{Conclusion}

In a nutshell, our empirical findings suggest that stock markets around the globe have been subject to contagion in the course of the subprime crisis, coming from the US stock market. In this respect, weak stability of international banks has been pivotal, because it has channeled adverse external shocks to stock markets. In particular, innovations on the mortgage market and stock market uncertainty have indirectly infected these markets via short-term lending. Beyond, the pre-eminent role of money markets for asset pricing is further underpinned by the widespread effect of liquidity risk on stock market correlations in the tranquil period.

The implications for policy makers and market participants are therefore extensive with regard to the evaluation of financial rescue actions during the recent financial crisis. First, economic progress has been threatened by bank instability. Hence, policy makers have rightly intended to foreclose contagion to their home economies. That means a stabilization of banks would have mitigated stock market contagion and accordingly negative repercussions to real economies, since banks do not have to reduce lending in response to a higher investment risk. As our analysis highlights, bank stability is particularly important, once the US mortgage market and stock market uncertainty seem to be sluggish. Thus, we document, how contagion has spread both across countries and across assets.

Second, the interbank market has formed a major channel for contagion. Especially, concerns related to banking instability, whereas liquidity risk has played a negligible role. Therefore, we present evidence for the involvement of the risk channel. In particular, our analysis exhibits that investors have been largely concerned about the considerable exposure of banks to the US mortgage market. Hence, our diagnosis suggests short-dated policy 
interventions for stabilizing financial institutions, to decouple the tumbling US mortgage market and stock markets. Furthermore, the absence of liquidity risk demonstrates that investors have trusted in the central bank's ability to sufficiently provide markets with shortterm debt anyway.

Third, policy actions should target at restoring bank stability and strengthening the US mortgage market, as they have been key for stock market contagion: (1) Bank equity has to be maintained. Hence, for emergency capital injections, central banks could act as lender of last resort. Further, authorities can either force banks to issue new capital or decree special accounting rules to suspend asset value adjustments. For emergency capital injections, central banks could also act as lender of last resort. Alternatively, directly purchasing mortgages or granting public aid to debtors might prevent banks from losses. (2) Investor confidence must be restored: An expansion of legal supervision to bank sponsored special purpose vehicles would therefore increase transparency of bank balance sheets. However, special accounting rules for banks would interfere with that objective. Alternatively, obligating stress tests for banks could potentially reduce uncertainty and information asymmetries on the side of investors. (3) Banks must be better prepared for future crisis: A long-term policy agenda should include an increase of both equity buffers and the quality of bank assets, because wellcapitalized banks have failed during the crisis just as highly leveraged ones; see Figure 3.

\section{[Figure 3]}

However, our empirical study is limited to the short-run. Above all, we do not provide any evidence regarding the long-term costs of those short-run policy actions discussed before. In fact, more empirical work is needed to investigate the long-run welfare effects of such rescue actions, taking into account the interaction of different asset markets and countries. Nevertheless, our study indicates that rescuing banks would have been necessary to protect stock markets from being harmed in order to avoid negative repercussions on real economies. 


\section{References}

Acharya, V. V., \& Pedersen, L. H. (2005). Asset Pricing with Liquidity Risk. Journal of Financial Economics , pp. 375-410.

Allen, F., \& Carletti, E. (2008). The Role of Liquidity in Financial Crises. Jackson Hole Symposium . Federal Reserve Bank of Kansas City.

Allen, F., \& Gale, D. (2000). Financial Contagion. Journal of Political Economy, 108, pp. 133.

Bae, K.-H., Karolyi, G. A., \& Stulz, R. M. (2003). A New Approach to Measuring Financial. Review of Financial Studies , No. 3, pp. 717-763.

Baig, T., \& Goldfajn, I. (1999). Financial Market Contagion in the Asian Crisis. 1-44. Urbana-Chamapaign: University of Illinois.

Bank of England. (2007). An Indicative Decomposition of LIBOR Spreads. Quarterly Bulletin , 4, pp. 498 - 499.

BNP Paribas. (2007, August 9). BNP Paribas Investment Partners temporaly suspends the calculation of the Net Asset Value of the following funds: Parvest Dynamic ABS, BNP Paribas ABS EURIBOR and BNP Paribas ABS EONIA. Paris, France.

Bollerslev, T. (1986). Generalized Autoregressive Conditional Heteroskedasticity. Journal of Econometrics , pp. 307-327.

Box, G. E., Jenkins, G. M., \& Reinsel, G. C. (1994). Time Series Analysis - Forecasting and Control (3 ed.). Englewood Cliffs (N.J.): Prentice Hall.

Brunnermeier, M. K. (2009). Deciphering the Liquidity and Credit Crunch 2007-08. Journal of Economic Perspectives, pp. 77-100.

Brunnermeier, M., \& Pedersen, L. H. (2008). Market Liquidity and Funding Liquidity. Review of Financial Studies .

Chiang, T. C., Jeon, B. N., \& Li, H. (2007). Dynamic Correlation Analysis of Financial Contagion: Evidence from Asian Markets. Journal of International Money and Finance , 26, pp. 1206-1228.

Corsetti, G., Pericoli, M., \& Sbracia, M. (2005). 'Some Contagion, Some Interdependence': More Pitfalls in Tests of Financial Contagion. Journal of International Money and Finance, 24, pp. 1177-1199.

Diamond, D. W., \& Dybvig, P. H. (1983). Bank Runs, Deposit Insurance, and Bank Runs. Journal of Political Economy, 91 (3), pp. 401-419.

Dodd, R. (2000). The Role of Derivatives in the East Asian Crisis. CEPA Working Paper Series III, No. 20 , pp. 1-27.

Dornbusch, R., Park, Y. C., \& Claessens, S. (2000). Contagion: Understanding How It Spreads. The World Bank Research Observer , 15 (2), pp. 177-197. 
Duca, J. V., Muellbauer, J., \& Murphy, A. (2010). Housing markets and the financial crisis of 2007-2009: Lessons for the future. Journal of Financial Stability, 6, pp. 203-217.

Eichengreen, B., Mody, A., Nedeljkovic, M., \& Sarno, L. (2009). How the Subprime Crisis Went Global - Evidence from Bank Credit Default Swap Spreads. NBER Working Paper No. 14904 .

Engle, R. (2002). Dynamic Conditional Correlation: A Simple Class of Multivariate Generalized Autoregressive Conditional Heteroskedasticity Models. Journal of Business \& Economic Statistics , 20 (3), pp. 339-350.

Engle, R. F., \& Sheppard, K. (2001). Theoretical and Empirical Properties of Dynamic Conditional Correlation Multivariate GARCH. NBER Working Paper No. W8554, S. 1-43.

Forbes, K., \& Rigobon, R. (2002). No Contagion, Only Interdependence: Measuring Stock Market Comovements. Journal of Finance , 57 (5), pp. 2223-2261.

Garber, P. M. (1998). Derivatives in International Capital Flow. NBER Working Paper No. 6623 , pp. 1-37.

Kacperczyk, M., \& Schnabl, P. (2010). When Safe Proved Risky: Commercial Paper during the Financial Crisis of 2007-2009. Journal of Economic Perspectives , 24 (1), pp. 29-50.

Kaminsky, G. L., Reinhart, C. M., \& Végh, C. A. (2003). The Unholy Trinity of Financial Contagion. Journal of Economic Perspectives .

Kim, B.-H., \& Kim, H. (2010). Spillover Effects of the US Finacnial Crisis on Financial Markets in Emerging Asian Countries. Working Paper .

Kindleberger, C. P. (1978). Manias, Panics and Crashes (4. Ausg.). Chippenham: Palgrave.

Kiyotaki, N., \& Moore, J. (2002). Balance-Sheet Contagion. American Economic Review , 2, pp. 46-50.

Kodres, L. E., \& Pritsker, M. (2002). A Rational Expectations Model of Financial Contagion. Journal of Finance , 57 (2), S. 769-799.

Lintner, J. (1965). The Valuation of Risk Assets and the Selection of Risky Investments in Stock Portfolios and Capital Budgets. Review of Economics and Statistics .

Longstaff, F. A. (2010). The Subprime Credit Crisis and Contagion in Financial Markets. Journal of Financial Economics .

Mandelbrot, B. (1963). The Variation of Certain Speculative Prices. Journal of Business, pp. 394-419.

Mishkin, F. S. (1991). Anatomy of Financial Crises. NBER Working Paper No. 3934 .

Modigliani, F., \& Miller, M. H. (1958). The Cost of Capital, Corporation Finance and the Theory of Investment. American Economic Review , pp. 261-297.

Pritsker, M. (2001). The Channnels for Financial Contagion. In S. Claessen, \& K. Forbes, Financial Contagion (1. Ausg., S. 67 - 98). New York: Springer. 
Reinhart, C. M., \& Rogoff, K. S. (2009). This Time is Different: Eight Centuries of Financial Folly. New Jersey: Princeton University Press.

Sharpe, W. F. (1964). Capital Asset Prices: A Theory of Market Equilibrium under Conditions of Risk. Journal of Finance, pp. 425-442.

Taylor, J. B., \& Williams, J. C. (2009). A Black Swan in the Money Market. American Economic Review , 1 (1), pp. 58-83.

van Rijckeghem, C., \& Weder, B. (2001). Sources of Contagion: Is it Finance or Trade? Journal of International Economics , 54, pp. 293-308.

Vayanos, D. (2004). Flight to Quality, Flight to Liquidity and the Pricing of Risk. NBER Working Paper 10327 . 
SP5

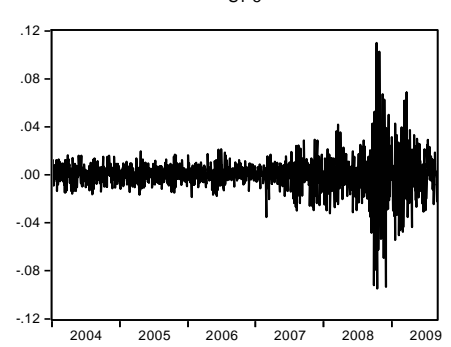

IBE

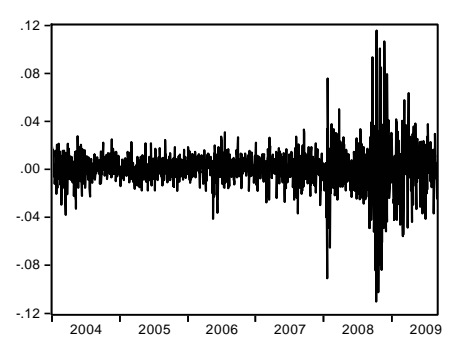

SMI

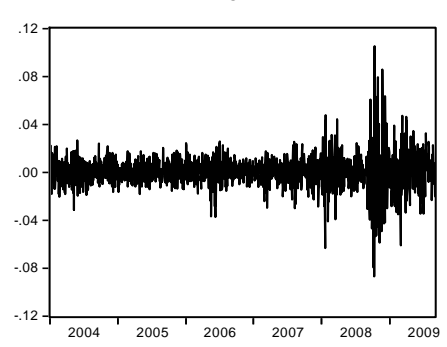

CSE

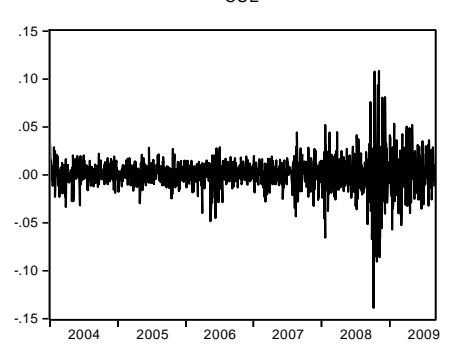

DAX

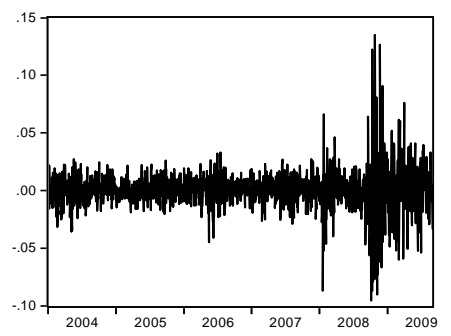

IRE

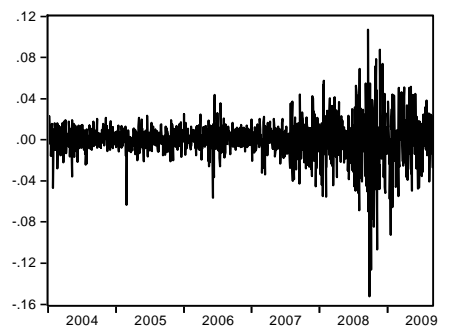

TS $X$

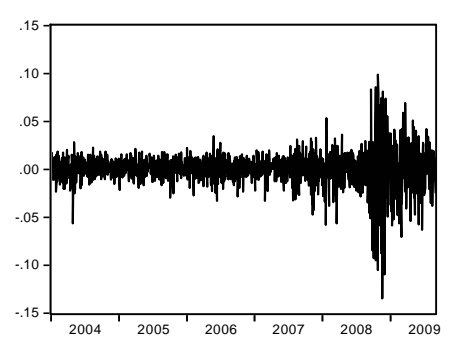

MBS

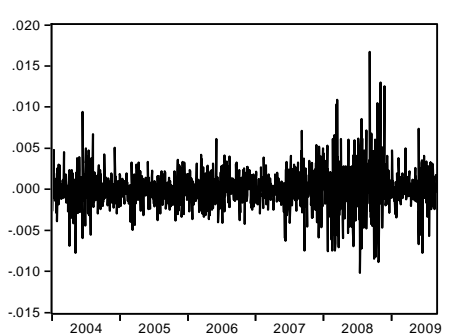

CAC
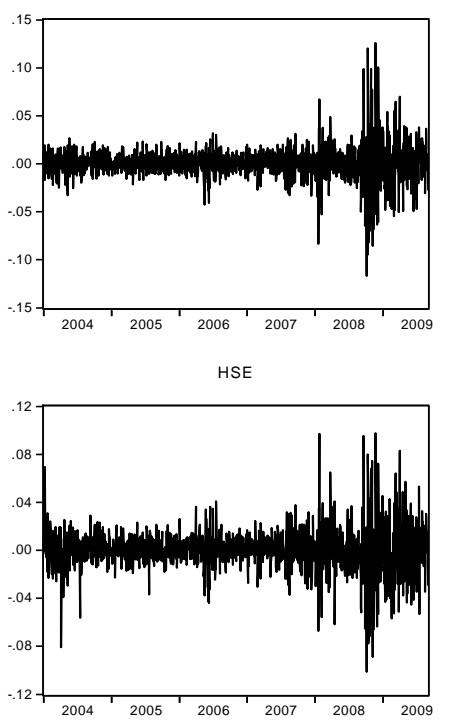

AsX

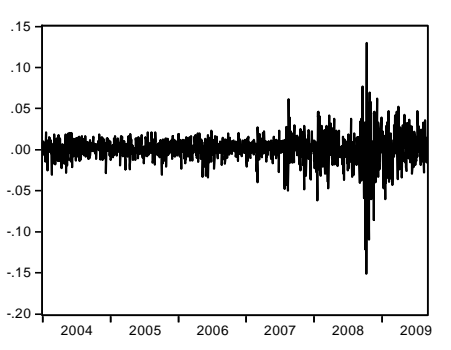

CDS

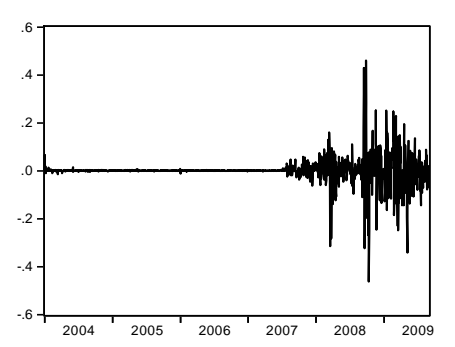

MIB
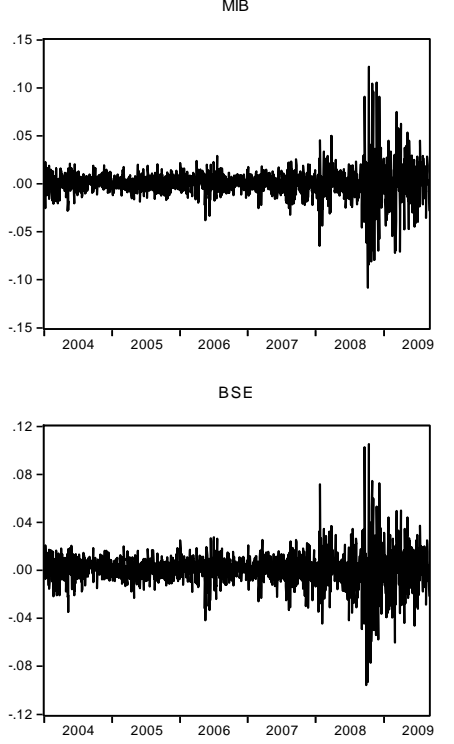

NZX

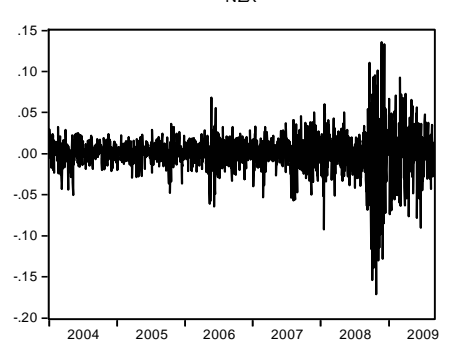

LIQ

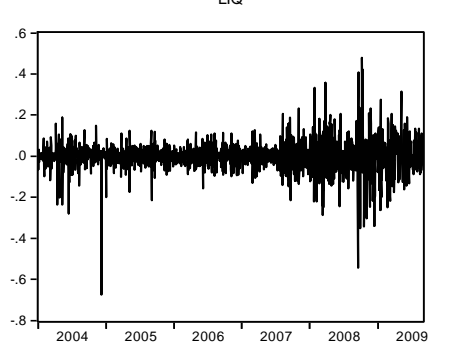

AEX
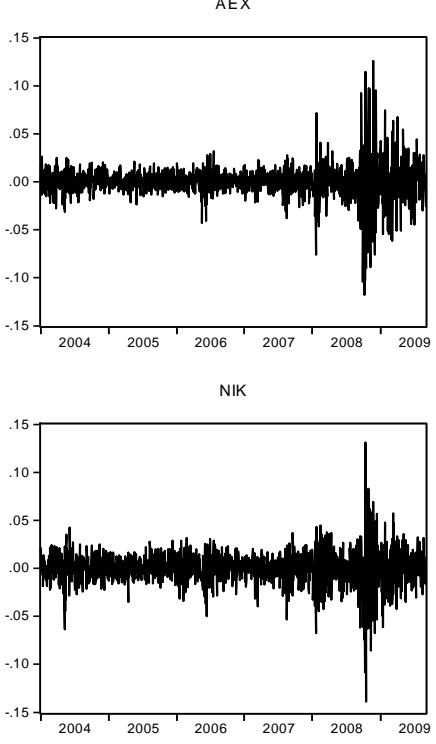

OSE

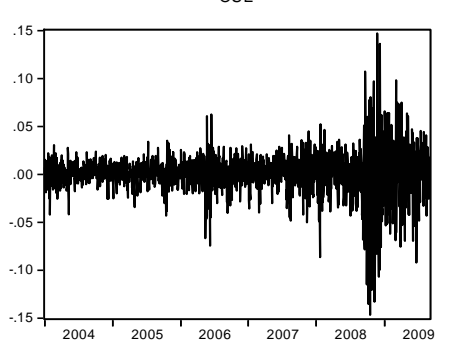

VIX

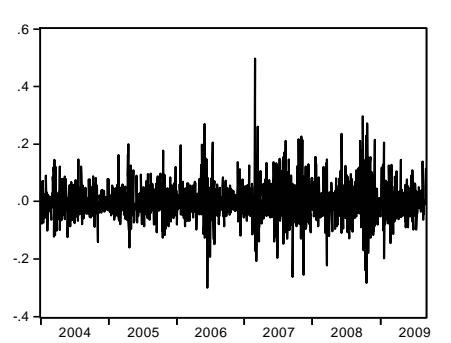

POP

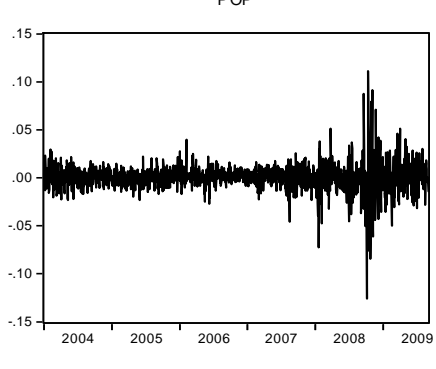

TSE

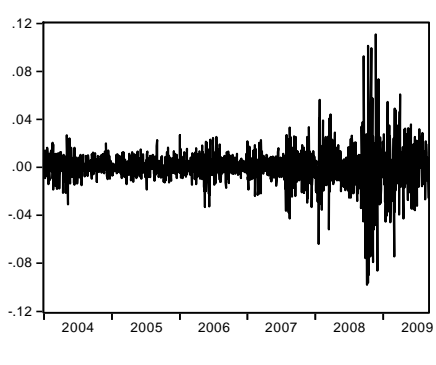

STS

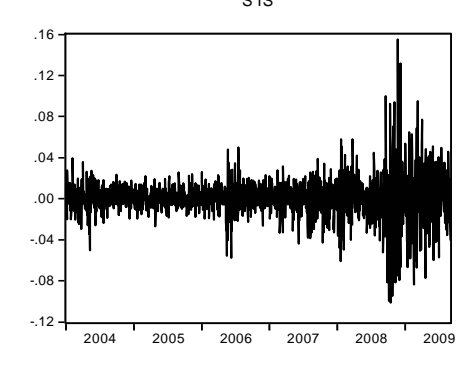

Figure 1: Time Series of Stock Market Returns, MBS Returns, Changes of Money Market Risk Premia and VIX Returns (April 1, 2004 to September 1, 2009) 
SP5_DAX

wer

SP5_IRE
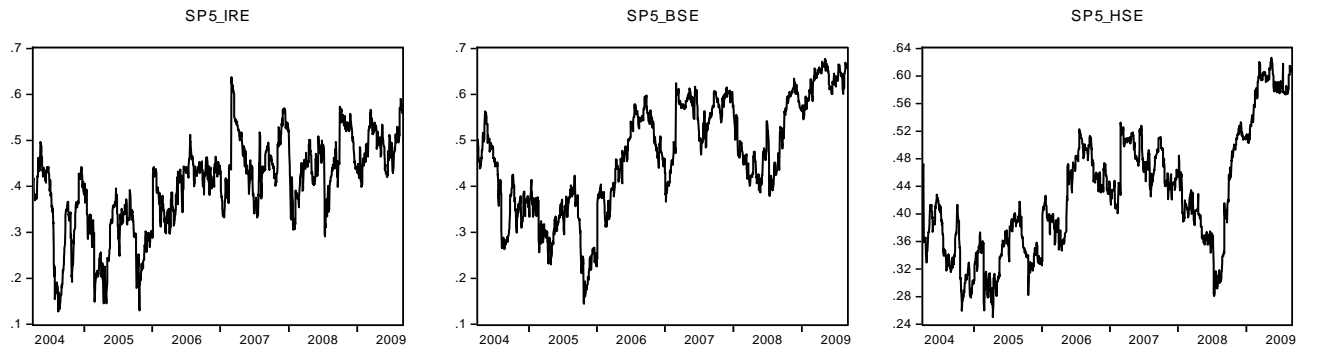

SP5_NZX
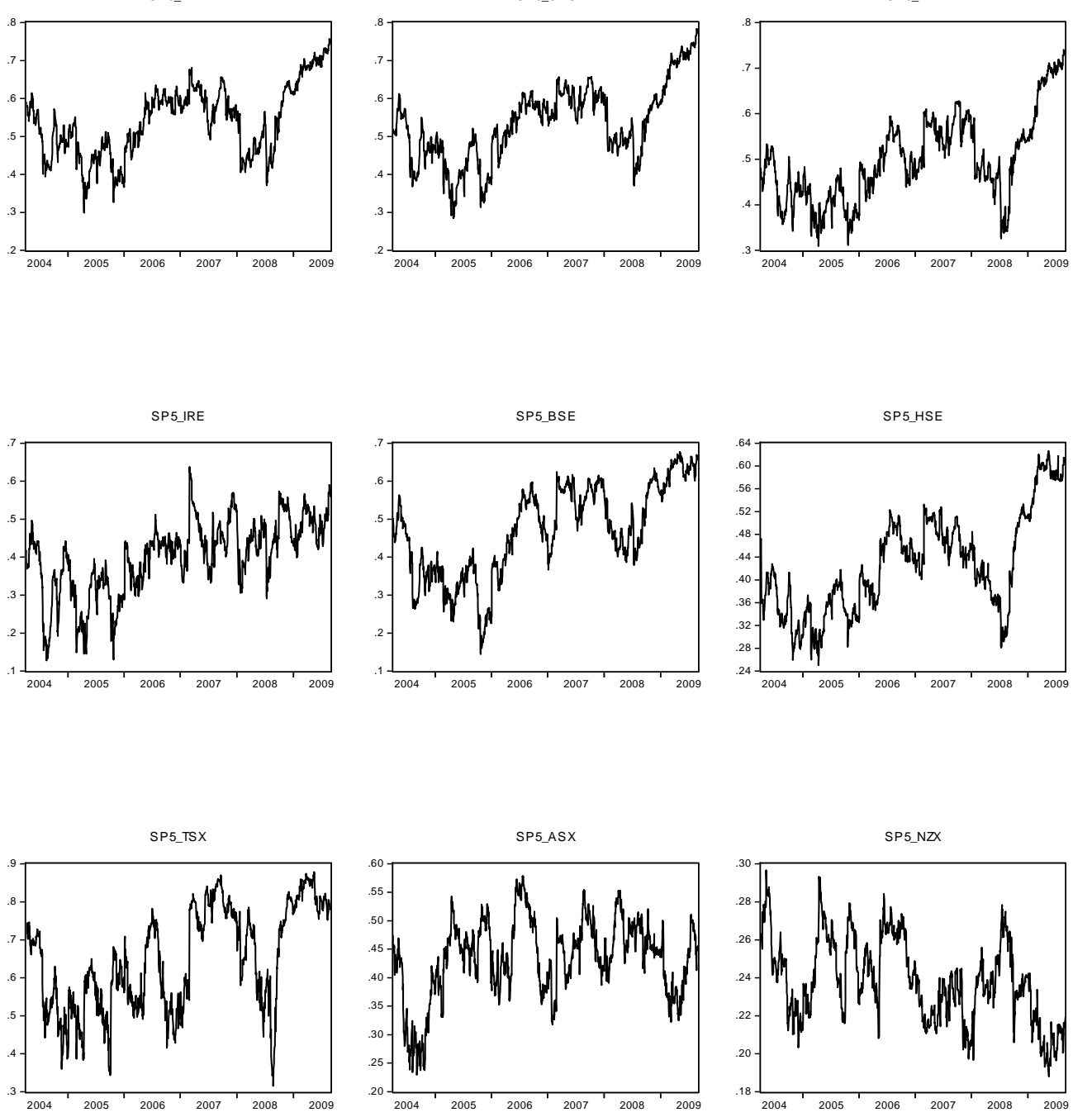
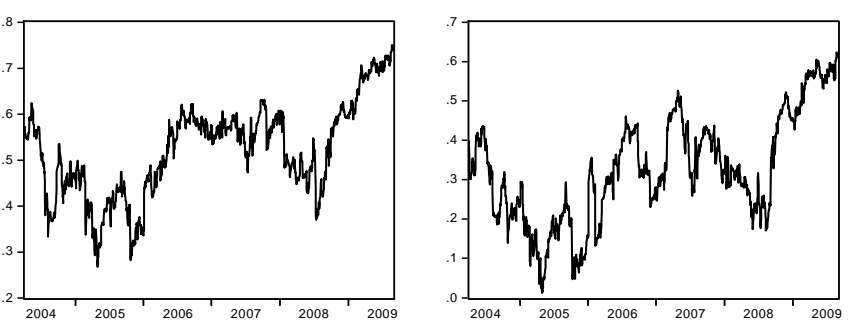

SP5_NIK
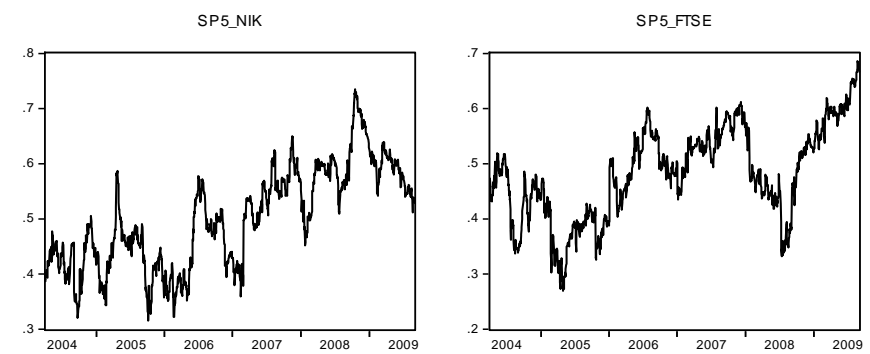

SP5_OSE
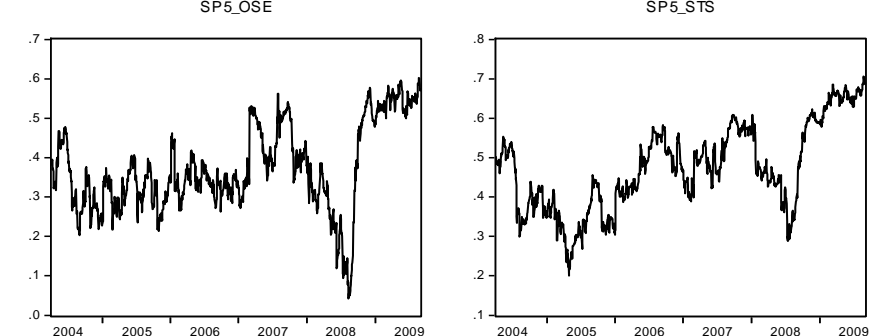

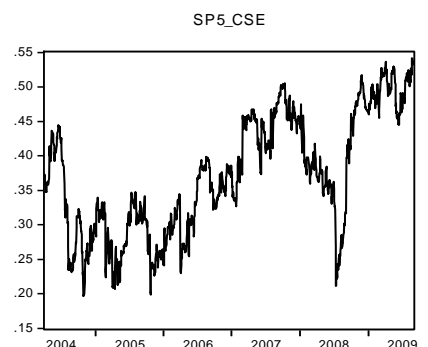

Figure 2: Time-varying Stock Market Correlations (April 1, 2004 to September 1, 2009) 


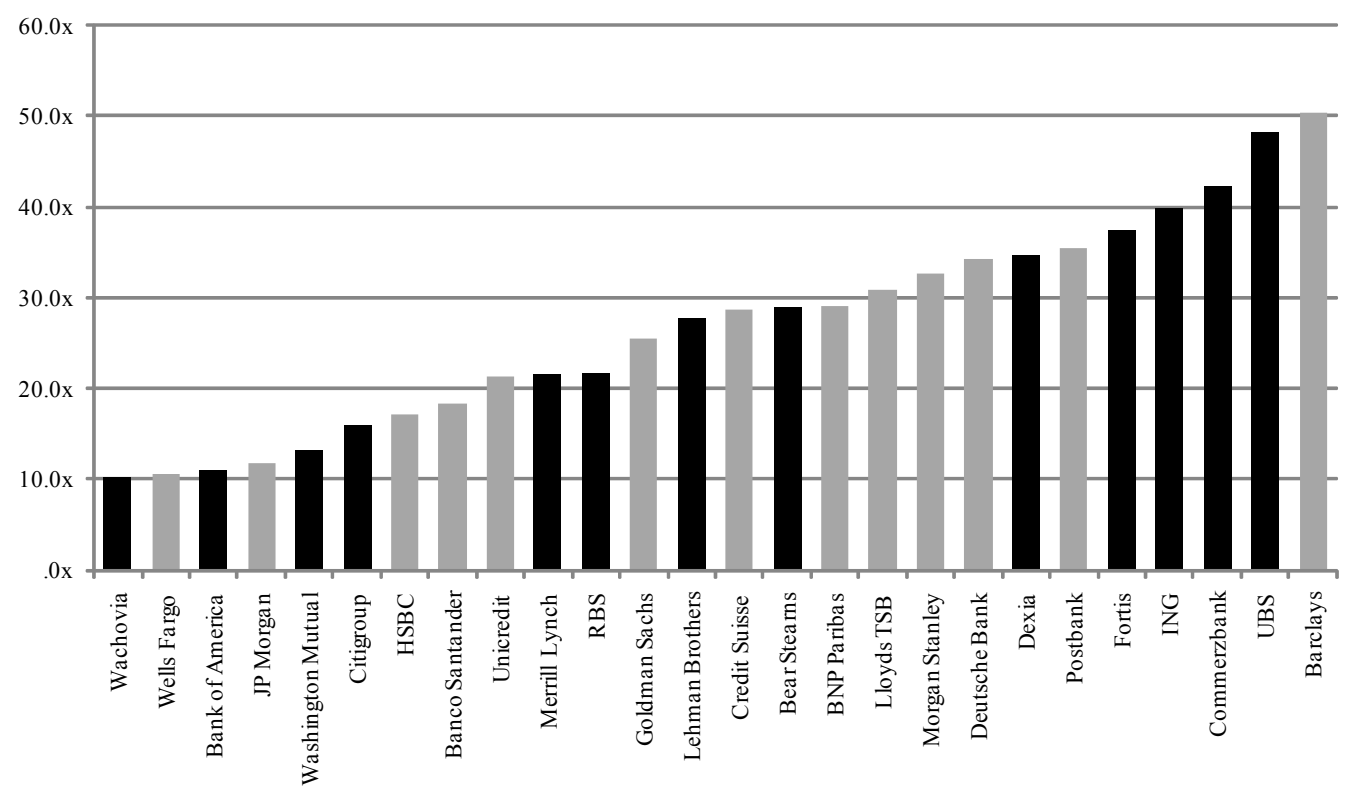

\begin{tabular}{|c|c|c|c|c|}
\hline & \multicolumn{2}{|c|}{ Government Aid Request } & \multicolumn{2}{|c|}{ No Government Aid Request } \\
\hline & Median & Mean & Median & Mean \\
\hline Leverage & $27.7 \mathrm{x}$ & $28.9 x$ & $28.7 \mathrm{x}$ & $26.0 \mathrm{x}$ \\
\hline \# of Banks & \multicolumn{2}{|c|}{13} & \multicolumn{2}{|c|}{13} \\
\hline$<20.0 \mathrm{x}$ & \multicolumn{2}{|c|}{4} & \multicolumn{2}{|c|}{4} \\
\hline $20.0 x-30.0 x$ & \multicolumn{2}{|c|}{4} & \multicolumn{2}{|c|}{4} \\
\hline $30.0 x-40.0 x$ & \multicolumn{2}{|c|}{3} & \multicolumn{2}{|c|}{4} \\
\hline$>40.0 \mathrm{x}$ & \multicolumn{2}{|c|}{2} & \multicolumn{2}{|c|}{1} \\
\hline
\end{tabular}

Figure 3a: Leverage ratios of major US and European banks just before the subprime crises (End of Fiscal Year 2006). Those later asking for government aid are black-shaded, while the rest is grey-shaded. Leverage describes total assets over common shareholder's equity.
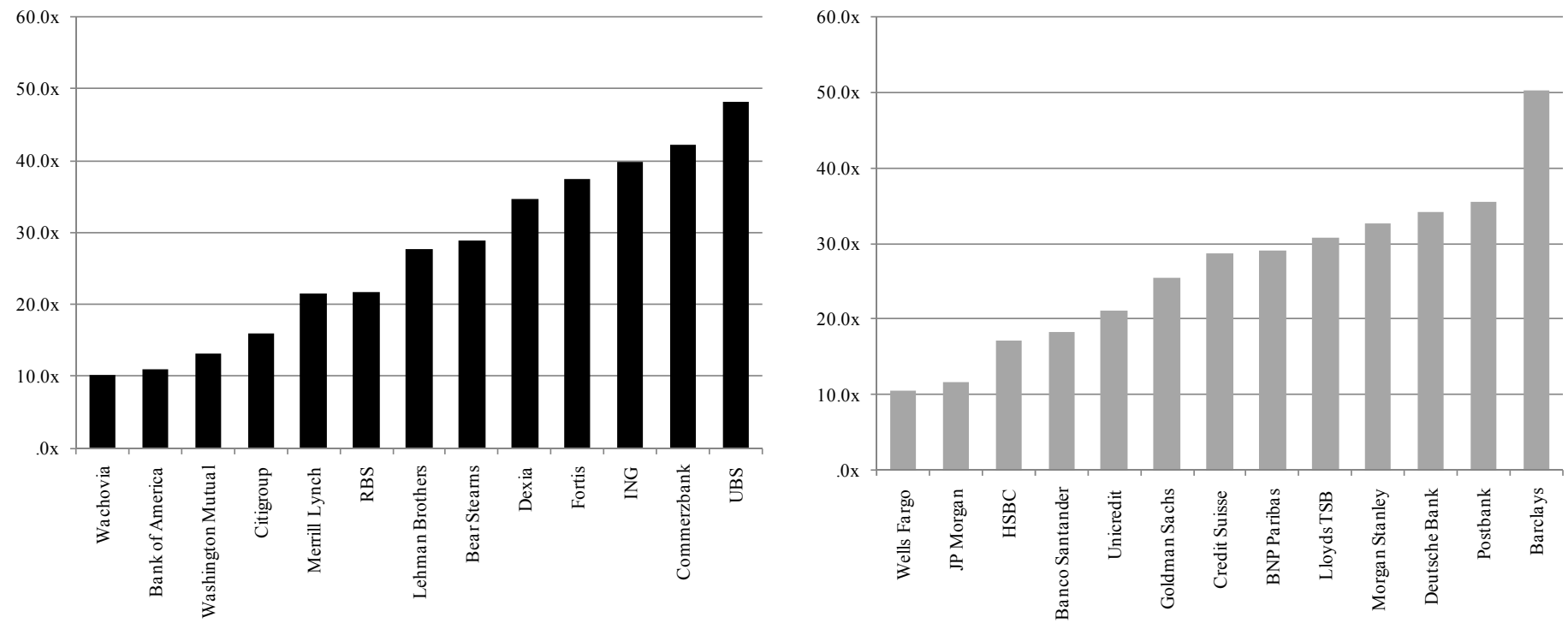

Figure 3a: Leverage ratios of major US and European banks just before the subprime crisis (End of Fiscal Year 2006). Those later asking for government aid are black-shaded, while the rest is grey-shaded. Leverage describes total assets over common shareholder's equity. 
Table I: Descriptive Statistics

This table shows summary statistics for all time series in our data. Jarque-Bera denotes a test statistic on the normality of the observation's distribution. $\mathrm{ADF}(0) / \mathrm{ADF}(1)$ denotes a test statistic on the observation's stationarity

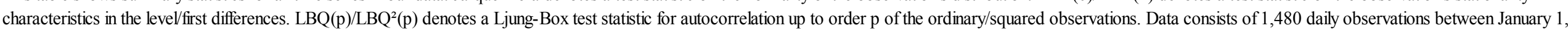

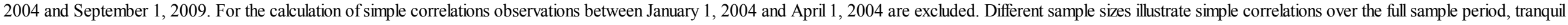
period and turmoil period. Statistics for counterparty and liquidity risk are usually computed after differentiating. Only ADF test statistics are determined using unmanipulated date. * denotes significance at the $1 \%$ level.

\begin{tabular}{|c|c|c|c|c|c|c|c|c|c|c|c|c|c|c|c|c|c|}
\hline \multirow[b]{2}{*}{ Stock Indices } & \multicolumn{5}{|c|}{ Stats } & \multicolumn{2}{|c|}{ Stationarity } & \multicolumn{3}{|c|}{ Normality } & \multicolumn{4}{|c|}{ Autocorrelation } & \multicolumn{3}{|c|}{ Simple Correlation with S\&P 500} \\
\hline & Mean & Median & Max & Min & Std. Dev. & $\mathrm{ADF}(0)$ & $\mathrm{ADF}(1)$ & Skewness & Kurtosis & Jarque-Bera & $\operatorname{LBQ}(10)$ & LBQ(20) & $\mathrm{LBQ}^{2}(10)$ & $\mathrm{LBQ}^{2}(20)$ & $\begin{array}{c}04 / 01 / 2004 \\
- \\
09 / 01 / 2009 \\
\end{array}$ & $\begin{array}{c}04 / 01 / 2004 \\
- \\
07 / 30 / 2007 \\
\end{array}$ & $\begin{array}{c}07 / 31 / 2007 \\
- \\
09 / 01 / 2009 \\
\end{array}$ \\
\hline S\&P 500 & 0.0000 & 0.0005 & 0.1096 & -0.0946 & 0.0141 & $-32.49 *$ & $-14.93 *$ & -0.2451 & 14.95 & $8,816.1^{*}$ & $60.59^{*}$ & $96.71 *$ & $1,386.10^{*}$ & $2,503.20^{*}$ & 1.0000 & 1.0000 & 1.0000 \\
\hline Dax & 0.0003 & 0.0008 & 0.1349 & -0.0954 & 0.0168 & $-39.39 *$ & $-15.74 *$ & 0.2750 & 14.47 & $8,126.5^{*}$ & $27.47^{*}$ & $46.94 *$ & $769.87 *$ & $1,519.40 *$ & 0.5985 & 0.4407 & 0.6341 \\
\hline CAC & 0.0002 & 0.0004 & 0.1261 & -0.1167 & 0.0169 & $-17.86^{*}$ & $-18.76^{*}$ & 0.0895 & 13.75 & $7,133.3^{*}$ & $65.92 *$ & $89.37 *$ & $966.48 *$ & $1,727.80^{*}$ & 0.5711 & 0.4331 & 0.5977 \\
\hline MIB & 0.0001 & 0.0006 & 0.1217 & -0.1082 & 0.0162 & $-7.79 *$ & $-19.09 *$ & 0.1031 & 13.87 & $7,283.8^{*}$ & $75.64 *$ & $124.03 *$ & $1,104.10^{*}$ & $1,955.70^{*}$ & 0.5429 & 0.4057 & 0.5652 \\
\hline AEX & 0.0001 & 0.0009 & 0.1259 & -0.1179 & 0.0172 & $-12.13 *$ & $-17.9^{*}$ & -0.1579 & 14.52 & $8,184.7^{*}$ & $45.95^{*}$ & $69.78^{*}$ & $1,240.40 *$ & $2,117.0^{*}$ & 0.5801 & 0.4178 & 0.6075 \\
\hline POPSI & 0.0003 & 0.0007 & 0.1114 & -0.1258 & 0.0140 & $-13.37 *$ & $-19.93^{*}$ & -0.2539 & 16.02 & $10,474.3^{*}$ & $45.22 *$ & $81.46^{*}$ & $756.49^{*}$ & $1,414.30 *$ & 0.4274 & 0.2083 & 0.4679 \\
\hline IBEX & 0.0004 & 0.0007 & 0.1157 & -0.1101 & 0.0164 & $-17.39^{*}$ & $-19.21 *$ & -0.1371 & 13.13 & $6,327.6^{*}$ & $46.98^{*}$ & $80.44 *$ & $1,042.10^{*}$ & $1,802.60 *$ & 0.5515 & 0.4103 & 0.5784 \\
\hline IRE & -0.0001 & 0.0010 & 0.1073 & -0.1525 & 0.0184 & $-36.96^{*}$ & $-15.3^{*}$ & -0.8784 & 11.68 & $4,841.5^{*}$ & $18.87^{*}$ & $49.85^{*}$ & $770.90 *$ & $1,305.10^{*}$ & 0.4696 & 0.2763 & 0.5030 \\
\hline HSE & 0.0003 & 0.0004 & 0.0977 & -0.1012 & 0.0174 & $-38.12 *$ & $-14.32 *$ & -0.0554 & 8.71 & $2,012.9^{*}$ & $20.61^{*}$ & $34.21^{*}$ & $588.07^{*}$ & $1,122.80 *$ & 0.4893 & 0.3269 & 0.5287 \\
\hline BSE & 0.0003 & 0.0009 & 0.1052 & -0.0959 & 0.0153 & $-11.69 *$ & $-13.75^{*}$ & -0.3032 & 10.74 & $3,714.3^{*}$ & $39.13^{*}$ & $60.12 *$ & $1,586.40^{*}$ & $2,657.70^{*}$ & 0.5535 & 0.3549 & 0.5932 \\
\hline NIKKEI & 0.0001 & 0.0004 & 0.1311 & -0.1390 & 0.0170 & $-26.28 *$ & $-14.94 *$ & -0.4614 & 11.65 & $4,662.4^{*}$ & $48.50^{*}$ & $67.37 *$ & $1,186.60 *$ & $1,786.70^{*}$ & 0.6077 & 0.3902 & 0.6751 \\
\hline FTSE & 0.0001 & 0.0004 & 0.1106 & -0.0980 & 0.0157 & $-17.43^{*}$ & $-16.39 *$ & -0.2180 & 13.34 & $6,599.5^{*}$ & $54.33^{*}$ & $72.01 *$ & $1,326.30 *$ & $2,203.10 *$ & 0.5665 & 0.3977 & 0.5944 \\
\hline SMI & 0.0003 & 0.0004 & 0.1051 & -0.0873 & 0.0137 & $-18.66^{*}$ & $-15.56^{*}$ & 0.0930 & 10.96 & $3,911.2 *$ & $70.38 *$ & $86.65^{*}$ & $1,152.60^{*}$ & $1,888.10^{*}$ & 0.4331 & 0.2875 & 0.4689 \\
\hline TSX & 0.0004 & 0.0020 & 0.0986 & -0.1347 & 0.0183 & $-16.93^{*}$ & $-15.49 *$ & -0.8957 & 11.51 & $4,668.2^{*}$ & $54.02 *$ & $74.10^{*}$ & $1,793.20 *$ & $3,419.40 *$ & 0.7551 & 0.5779 & 0.7861 \\
\hline ASX & 0.0004 & 0.0010 & 0.1300 & -0.1515 & 0.0169 & $-35.88^{*}$ & $-16.92 *$ & -0.9438 & 15.43 & $9,746.8^{*}$ & $20.56^{*}$ & $35.76^{*}$ & $1,228.20 *$ & $1,776.90^{*}$ & 0.4213 & 0.4071 & 0.4246 \\
\hline NZX & 0.0004 & 0.0020 & 0.1358 & -0.1710 & 0.0249 & $-38.17^{*}$ & $-13.25^{*}$ & -0.8244 & 10.34 & $3,490.6^{*}$ & $10.44^{*}$ & $43.03 *$ & $1,591.0^{*}$ & $2,888.40 *$ & 0.2022 & 0.2705 & 0.1886 \\
\hline OSE & 0.0005 & 0.0021 & 0.1466 & -0.1470 & 0.0238 & $-39.25^{*}$ & $-15.39 *$ & -0.6702 & 10.00 & $3,130.1^{*}$ & $19.63^{*}$ & $49.05^{*}$ & $1,579.50 *$ & $2,871.20^{*}$ & 0.4922 & 0.2644 & 0.5355 \\
\hline STS & 0.0004 & 0.0011 & 0.1551 & -0.1013 & 0.0202 & $-30.08^{*}$ & $-14.52 *$ & 0.1797 & 10.31 & $3,301.6^{*}$ & $28.70^{*}$ & $43.94 *$ & $826.99 *$ & $1,517.0^{*}$ & 0.5645 & 0.3648 & 0.6051 \\
\hline CSE & 0.0004 & 0.0011 & 0.1085 & -0.1391 & 0.0167 & $-16.85^{*}$ & $-19.74 *$ & -0.4290 & 12.51 & $5,626.9^{*}$ & $35.32 *$ & $58.71 *$ & $1,229.80^{*}$ & $2,101.40^{*}$ & 0.4598 & 0.2760 & 0.4974 \\
\hline \multicolumn{18}{|l|}{ Mortgage Market } \\
\hline MBS & 0.0000 & 0.0000 & 0.0167 & -0.0102 & 0.0023 & $-19.75^{*}$ & $-17.79 *$ & 0.3958 & 8.31 & $1,780.2 *$ & $36.78^{*}$ & $57.41 *$ & $275.95^{*}$ & $486.43^{*}$ & - & - & - \\
\hline \multicolumn{18}{|l|}{ Money Market } \\
\hline CDS & 0.0009 & 0.0000 & 0.4593 & -0.4635 & 0.0492 & -1.44 & $-7.81 *$ & -0.1915 & 28.49 & $40,063.5^{*}$ & $186.47^{*}$ & $243.95 *$ & $1,015.50 *$ & $1,367.80^{*}$ & - & - & - \\
\hline LIQ & -0.0004 & 0.0007 & 0.4796 & -0.6734 & 0.0764 & -3.24 & $-41.41 *$ & -0.5518 & 13.10 & $6,371.8^{*}$ & $30.45^{*}$ & $44.02 *$ & $259.39 *$ & $392.98^{*}$ & - & - & - \\
\hline \multicolumn{18}{|c|}{ Expected Volatility } \\
\hline VIX & 0.0003 & -0.0028 & 0.4960 & -0.2999 & 0.0635 & $-32.60 *$ & $-17.02 *$ & 0.6175 & 7.94 & $1,599.8^{*}$ & $58.1 *$ & $67.37 *$ & $190.42^{*}$ & $230.14^{*}$ & - & - & - \\
\hline
\end{tabular}




\section{Table II: Estimation of Dynamic Conditional Correlations}

This table reports parameter estimates and t-statistics for the two-step estimation approach of dynamic conditional correlations. AR denotes the return equation, GARCH the variance equation and DCC the time-varying correlation equation. We estimate both the AR and GARCH models with heteroscedasticity robust coefficient covariances according to Newey-West and Bollerslev-Wooldridge, respectively. The t-statistic is shown below the coefficient estimates. $* * *(* *, *)$ denotes the significance at the $1 \%(5 \%, 10 \%)$ level. The sample includes daily observations from January 1,2004 to September 1, 2009.

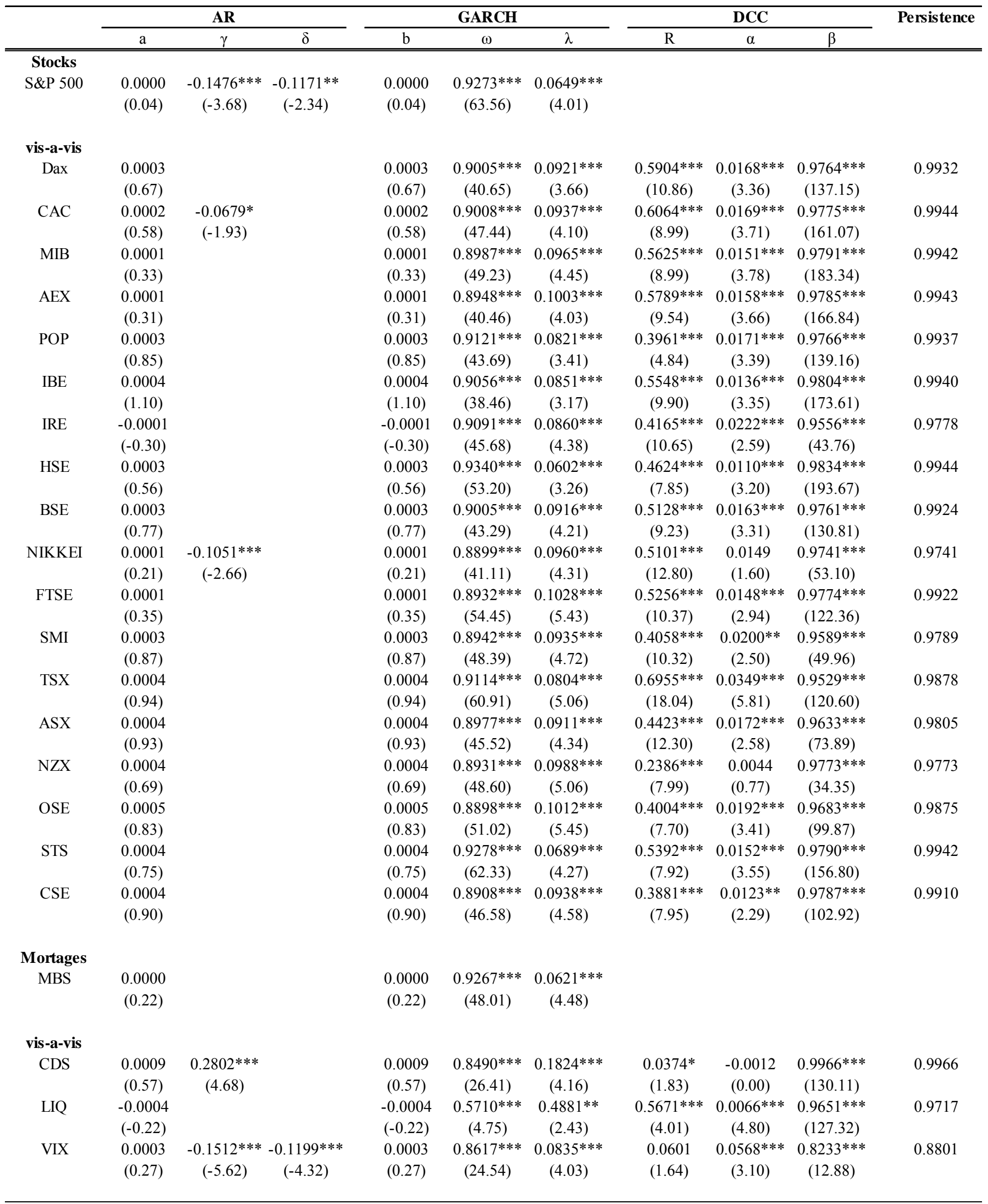




\section{Table III: Identification of Structural Changes of Dynamic Correlations}

Means and variances are calculated on time-varying stock market correlations for the full and turmoil period. Delta denotes the relative change of the average correlation in the turmoil period. The full sample period ranges from April 1, 2004 to September 1, 2009 and the turmoil period from July 31, 2007 to September 1, 2009.*** $(* *, *)$ denotes significance at the $1 \%(5 \%, 10 \%)$ level.

\begin{tabular}{|c|c|c|c|c|c|c|c|c|}
\hline \multirow[t]{2}{*}{ Index } & \multicolumn{2}{|c|}{ Adjusted Full Sample } & \multicolumn{2}{|c|}{ Turmoil } & \multicolumn{3}{|c|}{ t-statistic } & \multirow{2}{*}{$\begin{array}{c}\text { Delta } \\
\text { in } \%\end{array}$} \\
\hline & Mean Corr. & Variance & Mean Corr. & Variance & Difference & Std. Err. & t-value & \\
\hline Dax & 0.5266 & 0.0095 & 0.5797 & 0.0099 & $0.0531 * * *$ & 0.0050 & 10.70 & $9.6 \%$ \\
\hline $\mathrm{CAC}$ & 0.5172 & 0.0115 & 0.5921 & 0.0079 & $0.0749 * * *$ & 0.0047 & 15.84 & $13.5 \%$ \\
\hline MIB & 0.4813 & 0.0102 & 0.5562 & 0.0085 & $0.0749 * * *$ & 0.0047 & 15.79 & $14.5 \%$ \\
\hline AEX & 0.5063 & 0.0109 & 0.5752 & 0.0073 & $0.0689 * * *$ & 0.0046 & 15.10 & $12.8 \%$ \\
\hline POPSI & 0.3135 & 0.0174 & 0.4111 & 0.0136 & $0.0976^{* * *}$ & 0.0061 & 16.11 & $27.1 \%$ \\
\hline IBEX & 0.4827 & 0.0104 & 0.5495 & 0.0071 & $0.0668 * * *$ & 0.0045 & 14.91 & $13.0 \%$ \\
\hline IRE & 0.3956 & 0.0092 & 0.4658 & 0.0039 & $0.0703 * * *$ & 0.0037 & 19.16 & $16.4 \%$ \\
\hline HSE & 0.4178 & 0.0072 & 0.4783 & 0.0069 & $0.0605 * * *$ & 0.0042 & 14.46 & $13.5 \%$ \\
\hline BSE & 0.4573 & 0.0145 & 0.5544 & 0.0058 & $0.0971 * * *$ & 0.0045 & 21.53 & $19.3 \%$ \\
\hline NIKKEI & 0.4886 & 0.0110 & 0.5785 & 0.0029 & $0.0900 * * *$ & 0.0036 & 25.27 & $16.9 \%$ \\
\hline FTSE & 0.4671 & 0.0086 & 0.5294 & 0.0052 & $0.0624 * * *$ & 0.0039 & 15.97 & $12.5 \%$ \\
\hline SMI & 0.3824 & 0.0080 & 0.4220 & 0.0071 & $0.0397 * * *$ & 0.0043 & 9.25 & $9.9 \%$ \\
\hline TSX & 0.6347 & 0.0194 & 0.7393 & 0.0127 & $0.1046^{* * *}$ & 0.0060 & 17.33 & $15.3 \%$ \\
\hline ASX & 0.4309 & 0.0051 & 0.4504 & 0.0025 & $0.0194 * * *$ & 0.0028 & 6.89 & $4.4 \%$ \\
\hline NZX & 0.2393 & 0.0005 & 0.2268 & 0.0003 & $-0.0125 * * *$ & 0.0010 & -12.91 & $-5.4 \%$ \\
\hline OSE & 0.3604 & 0.0119 & 0.4211 & 0.0182 & $0.0607 * * *$ & 0.0064 & 9.45 & $15.6 \%$ \\
\hline STS & 0.4582 & 0.0135 & 0.5402 & 0.0092 & $0.0821 * * *$ & 0.0051 & 16.11 & $16.5 \%$ \\
\hline CSE & 0.3592 & 0.0089 & 0.4383 & 0.0045 & $0.0791 * * *$ & 0.0038 & 20.98 & $19.9 \%$ \\
\hline
\end{tabular}


Table IV: Regression Results for Dynamic Correlations vis-à-vis the US Stock Market (Daily Data) - Part A

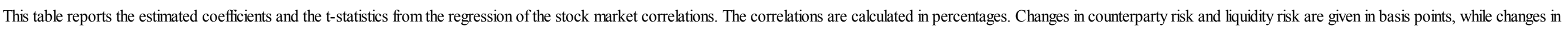

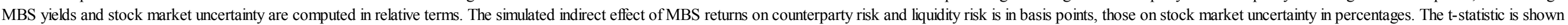

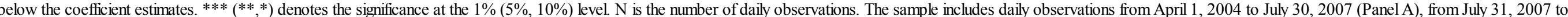
September 1, 2009 (Panel B).

Panel A: Pre-Crises Period Regression

\begin{tabular}{|c|c|c|c|c|c|c|c|c|c|c|c|c|c|c|c|c|c|c|}
\hline \multirow{2}{*}{ 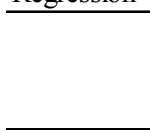 } & \multicolumn{3}{|c|}{1} & \multicolumn{3}{|c|}{2} & \multicolumn{3}{|c|}{3} & \multicolumn{3}{|c|}{4} & \multicolumn{3}{|c|}{5} & \multicolumn{3}{|c|}{$\begin{array}{c}6 \\
\text { IBEX }\end{array}$} \\
\hline & (1) & (2) & (3) & (1) & (2) & (3) & (1) & (2) & (3) & (1) & $(2)$ & (3) & (1) & (2) & (3) & (1) & (2) & (3) \\
\hline $\mathrm{C}$ & $\begin{array}{c}0.0420^{* * * *} \\
(3.27)\end{array}$ & $\begin{array}{c}0.0417^{* * *} \\
(3.26)\end{array}$ & $\begin{array}{c}0.0431 * * * \\
(3.36)\end{array}$ & $\begin{array}{c}0.0497^{* * *} \\
(3.64)\end{array}$ & $\begin{array}{c}0.0494 * * * \\
(3.63)\end{array}$ & $\begin{array}{c}0.0508^{* * *} \\
(3.72)\end{array}$ & $\begin{array}{c}0.0574^{* * *} \\
(4.53)\end{array}$ & $\begin{array}{c}0.0566^{* * *} \\
(4.49)\end{array}$ & $\begin{array}{c}0.0577^{* * *} \\
(4.56)\end{array}$ & $\begin{array}{c}0.0277 * * \\
(2.15)\end{array}$ & $\begin{array}{c}0.0283^{* *} \\
(2.20)\end{array}$ & $\begin{array}{c}0.0294 * * \\
(2.27)\end{array}$ & $\begin{array}{l}0.0209 \\
(1.22)\end{array}$ & $\begin{array}{c}0.0209 \\
(1.22)\end{array}$ & $\begin{array}{c}0.0247 \\
(1.45)\end{array}$ & $\begin{array}{c}0.0451^{* * *} \\
(4.17)\end{array}$ & $\begin{array}{c}0.0443 * * * \\
(4.15)\end{array}$ & $\begin{array}{c}0.0461 * * * \\
(4.32)\end{array}$ \\
\hline MBS & $\begin{array}{c}-0.1223 \\
(-0.45)\end{array}$ & $\begin{array}{r}-0.1797 \\
(-0.65)\end{array}$ & $\begin{array}{c}-0.2379 \\
(-0.85)\end{array}$ & $\begin{array}{c}-0.2393 \\
(-0.82)\end{array}$ & $\begin{array}{c}-0.3113 \\
(-1.06)\end{array}$ & $\begin{array}{r}-0.3591 \\
(-1.21)\end{array}$ & $\begin{array}{c}-0.0953 \\
(-0.35)\end{array}$ & $\begin{array}{r}-0.1569 \\
(-0.58)\end{array}$ & $\begin{array}{c}-0.2033 \\
(-0.74)\end{array}$ & $\begin{array}{c}-0.2551 \\
(-0.92)\end{array}$ & $\begin{array}{c}-0.3408 \\
(-1.23)\end{array}$ & $\begin{array}{c}-0.3809 \\
(-1.36)\end{array}$ & $\begin{array}{c}-0.0024 \\
(-0.01)\end{array}$ & $\begin{array}{c}-0.1168 \\
(-0.32)\end{array}$ & $\begin{array}{c}-0.2674 \\
(-0.72)\end{array}$ & $\begin{array}{c}-0.3066 \\
(-1.32)\end{array}$ & $\begin{array}{c}-0.4084^{*} \\
(-1.78)\end{array}$ & $\begin{array}{c}-0.4731^{* *} \\
(-2.04)\end{array}$ \\
\hline CDS & $\begin{array}{c}0.9797 * * \\
(2.41)\end{array}$ & $\begin{array}{c}0.6525 \\
(1.34)\end{array}$ & $\begin{array}{r}0.6809 \\
(1.40)\end{array}$ & $\begin{array}{c}1.3675^{* * * *} \\
(3.16)\end{array}$ & $\begin{array}{c}1.0294 * * \\
(1.99)\end{array}$ & $\begin{array}{c}1.0471 * * \\
(2.02)\end{array}$ & $\begin{array}{c}1.3097 * * * \\
(3.26)\end{array}$ & $\begin{array}{c}1.0871^{* *} \\
(2.26)\end{array}$ & $\begin{array}{c}1.1108^{* *} \\
(2.31)\end{array}$ & $\begin{array}{c}1.5937 * * * \\
(3.89)\end{array}$ & $\begin{array}{c}1.3037 * * * \\
(2.66)\end{array}$ & $\begin{array}{c}1.3175^{* * * *} \\
(2.68)\end{array}$ & $\begin{array}{c}1.5346^{* * *} \\
(2.82)\end{array}$ & $\begin{array}{c}1.0749^{*} \\
(1.65)\end{array}$ & $\begin{array}{c}1.1281^{*} \\
(1.74)\end{array}$ & $\begin{array}{c}1.2117 * * * \\
(3.53)\end{array}$ & $\begin{array}{c}1.0443 * * * \\
(2.57)\end{array}$ & $\begin{array}{c}1.0663^{* * *} \\
(2.63)\end{array}$ \\
\hline LIQ & $\begin{array}{c}0.0227^{* *} \\
(2.47)\end{array}$ & $\begin{array}{c}0.0243^{* * *} \\
(2.57)\end{array}$ & $\begin{array}{c}0.0270^{* * *} \\
(2.73)\end{array}$ & $\begin{array}{c}0.0235^{* *} \\
(2.40)\end{array}$ & $\begin{array}{c}0.0256^{* *} \\
(2.55)\end{array}$ & $\begin{array}{c}0.0265^{* *} \\
(2.52)\end{array}$ & $\begin{array}{c}0.0217^{* *} \\
(2.38)\end{array}$ & $\begin{array}{c}0.0216^{* *} \\
(2.32)\end{array}$ & $\begin{array}{c}0.0239^{* *} \\
(2.46)\end{array}$ & $\begin{array}{c}0.0229^{* *} \\
(2.47)\end{array}$ & $\begin{array}{c}0.0287^{* * *} \\
(3.03)\end{array}$ & $\begin{array}{c}0.0295^{* * *} \\
(2.96)\end{array}$ & $\begin{array}{c}0.0218^{*} \\
(1.78)\end{array}$ & $\begin{array}{c}0.0270^{* *} \\
(2.14)\end{array}$ & $\begin{array}{c}0.0311^{* *} \\
(2.36)\end{array}$ & $\begin{array}{c}0.0227^{* * *} \\
(2.93)\end{array}$ & $\begin{array}{c}0.0245^{* * *} \\
(3.12)\end{array}$ & $\begin{array}{c}0.0256^{* * *} \\
(3.12)\end{array}$ \\
\hline VIX & $\begin{array}{c}0.0104 \\
(1.36)\end{array}$ & $\begin{array}{c}0.0059 \\
(0.74)\end{array}$ & $\begin{array}{c}0.0050 \\
(0.63)\end{array}$ & $\begin{array}{c}0.0124 \\
(1.52)\end{array}$ & $\begin{array}{c}0.0073 \\
(0.86)\end{array}$ & $\begin{array}{c}0.0068 \\
(0.80)\end{array}$ & $\begin{array}{c}0.0152^{* *} \\
(2.00)\end{array}$ & $\begin{array}{c}0.0083 \\
(1.05)\end{array}$ & $\begin{array}{c}0.0075 \\
(0.95)\end{array}$ & $\begin{array}{c}0.0014 \\
(0.18)\end{array}$ & $\begin{array}{c}0.0006 \\
(0.07)\end{array}$ & $\begin{array}{c}0.0003 \\
(0.03)\end{array}$ & $\begin{array}{c}-0.0036 \\
(-0.35)\end{array}$ & $\begin{array}{c}-0.0089 \\
(-0.83)\end{array}$ & $\begin{array}{c}-0.0100 \\
(-0.93)\end{array}$ & $\begin{array}{c}0.0180 * * * \\
(2.79)\end{array}$ & $\begin{array}{c}0.0104 \\
(1.55)\end{array}$ & $\begin{array}{c}0.0099 \\
(1.48)\end{array}$ \\
\hline CDS*LIQ & & $\begin{array}{c}9.1497 * \\
(1.71)\end{array}$ & $\begin{array}{c}11.7088 \\
(1.60)\end{array}$ & & $\begin{array}{c}11.3972 * * \\
(2.00)\end{array}$ & $\begin{array}{c}11.1346 \\
(1.43)\end{array}$ & & $\begin{array}{c}8.4272 \\
(1.60)\end{array}$ & $\begin{array}{c}10.5640 \\
(1.46)\end{array}$ & & $\begin{array}{c}15.1473 * * * \\
(2.81)\end{array}$ & $\begin{array}{c}15.7970^{* *} \\
(2.14)\end{array}$ & & $\begin{array}{c}18.8573 * * * \\
(2.64)\end{array}$ & $\begin{array}{c}26.7532 * * * \\
\quad(2.74)\end{array}$ & & $\begin{array}{c}14.5226 * * * \\
(3.25)\end{array}$ & $\begin{array}{c}15.3764 * * \\
(2.53)\end{array}$ \\
\hline CDS*VIX & & $\begin{array}{l}6.5118 \\
(1.32)\end{array}$ & $\begin{array}{l}5.8038 \\
(1.17)\end{array}$ & & $\begin{array}{c}6.8540 \\
(1.31)\end{array}$ & $\begin{array}{l}6.2607 \\
(1.19)\end{array}$ & & $\begin{array}{r}4.1082 \\
(0.84)\end{array}$ & $\begin{array}{r}3.5192 \\
(0.72)\end{array}$ & & $\begin{array}{l}6.9006 \\
(1.39)\end{array}$ & $\begin{array}{r}6.5007 \\
(1.30)\end{array}$ & & $\begin{array}{r}9.8771 \\
(1.50)\end{array}$ & $\begin{array}{r}8.7605 \\
(1.33)\end{array}$ & & $\begin{array}{c}3.5342 \\
(0.86)\end{array}$ & $\begin{array}{c}2.8819 \\
(0.70)\end{array}$ \\
\hline LIQ*VIX & & $\begin{array}{c}0.1408 \\
(1.13)\end{array}$ & $\begin{array}{c}0.0809 \\
(0.61)\end{array}$ & & $\begin{array}{c}0.1648 \\
(1.24)\end{array}$ & $\begin{array}{l}0.1091 \\
(0.78)\end{array}$ & & $\begin{array}{c}0.3598^{* * *} \\
(2.92)\end{array}$ & $\begin{array}{c}0.3059 * * \\
(2.35)\end{array}$ & & $\begin{array}{c}-0.1546 \\
(-1.23)\end{array}$ & $\begin{array}{c}-0.1758 \\
(-1.32)\end{array}$ & & $\begin{array}{c}0.0813 \\
(0.49)\end{array}$ & $\begin{array}{c}0.1060 \\
(0.60)\end{array}$ & & $\begin{array}{c}0.3973 * * * \\
(3.81)\end{array}$ & $\begin{array}{c}0.3611^{* * *} \\
\quad(3.29)\end{array}$ \\
\hline MBS_CDS & & & $\begin{array}{c}-1,819.1150 \\
(-0.54)\end{array}$ & & & $\begin{array}{c}113.4740 \\
(0.03)\end{array}$ & & & $\begin{array}{c}-1,530.5460 \\
(-0.46)\end{array}$ & & & $\begin{array}{c}-443.7025 \\
(-0.13)\end{array}$ & & & $\begin{array}{c}-5,171.7330 \\
(-1.15)\end{array}$ & & & $\begin{array}{c}-587.0002 \\
(-0.21)\end{array}$ \\
\hline MBS_LIQ & & & $\begin{array}{c}0.7802 * * \\
(2.18)\end{array}$ & & & $\begin{array}{c}0.7777^{* *} \\
(2.04)\end{array}$ & & & $\begin{array}{c}0.6416^{*} \\
(1.81)\end{array}$ & & & $\begin{array}{r}0.5066 \\
(1.40)\end{array}$ & & & $\begin{array}{c}1.2233^{* *} \\
(2.56)\end{array}$ & & & $\begin{array}{c}0.8350 * * * \\
(2.80)\end{array}$ \\
\hline MBS_VIX & & & $\begin{array}{c}0.7659 \\
(1.14)\end{array}$ & & & $\begin{array}{c}0.5441 \\
(0.77)\end{array}$ & & & $\begin{array}{c}0.7077 \\
(1.07)\end{array}$ & & & $\begin{array}{c}0.1500 \\
(0.22)\end{array}$ & & & $\begin{array}{c}-0.5467 \\
(-0.61)\end{array}$ & & & $\begin{array}{c}0.2567 \\
(0.46)\end{array}$ \\
\hline Adj. $R^{2}$ & 0.9744 & 0.9746 & 0.9748 & 0.9751 & 0.9753 & 0.9755 & 0.9670 & 0.9675 & 0.9677 & 0.9788 & 0.9791 & 0.9791 & 0.9787 & 0.9789 & 0.9791 & 0.9787 & 0.9794 & 0.9796 \\
\hline PUR & $3.75 \%$ & $4.42 \%$ & $5.23 \%$ & $4.27 \%$ & $5.08 \%$ & $5.69 \%$ & $4.57 \%$ & $5.93 \%$ & $6.52 \%$ & $4.51 \%$ & $5.72 \%$ & $5.96 \%$ & $3.39 \%$ & $4.44 \%$ & $5.33 \%$ & $5.60 \%$ & $8.55 \%$ & $9.49 \%$ \\
\hline F-value & $1,464.49$ & $1,293.35$ & $1,160.77$ & $1,503.24$ & $1,329.79$ & $1,190.97$ & $1,126.96$ & $1,002.96$ & 898.15 & $1,772.17$ & $1,574.19$ & $1,404.24$ & $1,763.53$ & $1,563.74$ & $1,404.52$ & $1,768.49$ & $1,601.90$ & $1,440.29$ \\
\hline Obs. & 868 & 868 & 868 & 868 & 868 & 868 & 868 & 868 & 868 & 868 & 868 & 868 & 868 & 868 & 868 & 868 & 868 & 868 \\
\hline
\end{tabular}




\section{Table IV: Regression Results for Dynamic Correlations vis-à-vis the US Stock Market (Daily Data) - Part B}

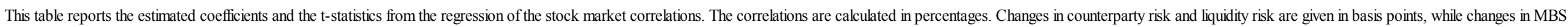

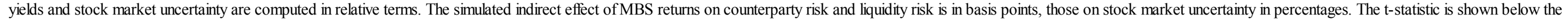

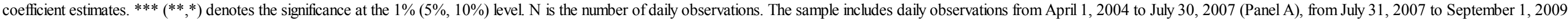
(Panel B).

\section{Panel A: Pre-Crises Period} Regression

\begin{tabular}{|c|c|c|c|c|c|c|c|c|c|c|c|c|c|c|c|c|c|c|}
\hline & \multicolumn{3}{|c|}{7} & \multicolumn{3}{|c|}{$\begin{array}{c}8 \\
\text { BSE }\end{array}$} & \multicolumn{3}{|c|}{$\begin{array}{c}9 \\
\text { HSE }\end{array}$} & \multicolumn{3}{|c|}{$\begin{array}{c}10 \\
\text { NIKKEI }\end{array}$} & \multicolumn{3}{|c|}{$\begin{array}{c}11 \\
\text { FTSE }\end{array}$} & \multicolumn{3}{|c|}{$\begin{array}{c}12 \\
\text { SMI }\end{array}$} \\
\hline & (1) & (2) & (3) & (1) & (2) & (3) & $(1)$ & (2) & (3) & $(1)$ & (2) & (3) & (1) & (2) & (3) & $(1)$ & (2) & (3) \\
\hline $\mathrm{C}$ & $\begin{array}{c}0.0323^{*} \\
(1.71)\end{array}$ & $\begin{array}{c}0.0312^{*} \\
(1.68)\end{array}$ & $\begin{array}{c}0.0342^{*} \\
(1.84)\end{array}$ & $\begin{array}{c}0.0304^{* *} \\
(2.03)\end{array}$ & $\begin{array}{c}0.0298^{* *} \\
(2.00)\end{array}$ & $\begin{array}{c}0.0321^{* *} \\
(2.15)\end{array}$ & $\begin{array}{c}0.0152 \\
(1.45)\end{array}$ & $\begin{array}{c}0.0147 \\
(1.41)\end{array}$ & $\begin{array}{c}0.0150 \\
(1.45)\end{array}$ & $\begin{array}{c}0.0316^{* * *} \\
(2.64)\end{array}$ & $\begin{array}{c}0.0310^{* * *} \\
(2.61)\end{array}$ & $\begin{array}{c}0.0320^{* * *} \\
(2.69)\end{array}$ & $\begin{array}{c}0.0482 * * * \\
(4.21)\end{array}$ & $\begin{array}{c}0.0485^{* * *} \\
(4.26)\end{array}$ & $\begin{array}{c}0.0503^{* * *} \\
(4.40)\end{array}$ & $\begin{array}{c}0.0398^{* *} \\
(2.18)\end{array}$ & $\begin{array}{c}0.0392^{* *} \\
(2.15)\end{array}$ & $\begin{array}{c}0.0444^{* *} \\
(2.44)\end{array}$ \\
\hline MBS & $\begin{array}{c}0.5656 \\
(1.40)\end{array}$ & $\begin{array}{c}0.3880 \\
(0.97)\end{array}$ & $\begin{array}{c}0.2669 \\
(0.66)\end{array}$ & $\begin{array}{r}-0.2041 \\
(-0.64)\end{array}$ & $\begin{array}{c}-0.2978 \\
(-0.93)\end{array}$ & $\begin{array}{c}-0.3872 \\
(-1.19)\end{array}$ & $\begin{array}{c}-0.0909 \\
(-0.41)\end{array}$ & $\begin{array}{c}-0.1738 \\
(-0.78)\end{array}$ & $\begin{array}{c}-0.1630 \\
(-0.72)\end{array}$ & $\begin{array}{c}0.0652 \\
(0.25)\end{array}$ & $\begin{array}{c}-0.0375 \\
(-0.15)\end{array}$ & $\begin{array}{c}-0.0786 \\
(-0.30)\end{array}$ & $\begin{array}{c}-0.2969 \\
(-1.21)\end{array}$ & $\begin{array}{c}-0.4064^{*} \\
(-1.66)\end{array}$ & $\begin{array}{c}-0.4734^{*} \\
(-1.91)\end{array}$ & $\begin{array}{c}-0.4432 \\
(-1.13)\end{array}$ & $\begin{array}{c}-0.5624 \\
(-1.43)\end{array}$ & $\begin{array}{c}-0.7497 \\
(-1.90)\end{array}$ \\
\hline CDS & $\begin{array}{c}2.0492 * * * \\
(3.43)\end{array}$ & $\begin{array}{c}1.2265^{*} \\
(1.73)\end{array}$ & $\begin{array}{c}1.2778^{*} \\
(1.81)\end{array}$ & $\begin{array}{c}1.5183 * * * \\
(3.20)\end{array}$ & $\begin{array}{c}1.2200^{* *} \\
(2.15)\end{array}$ & $\begin{array}{c}1.2537 * * \\
(2.21)\end{array}$ & $\begin{array}{c}1.1027^{* * *} \\
(3.32)\end{array}$ & $\begin{array}{c}0.9864 * * \\
(2.49)\end{array}$ & $\begin{array}{c}0.9740^{* *} \\
(2.47)\end{array}$ & $\begin{array}{c}0.9158^{* *} \\
(2.41)\end{array}$ & $\begin{array}{c}0.5308 \\
(1.18)\end{array}$ & $\begin{array}{l}0.5515 \\
(1.22)\end{array}$ & $\begin{array}{c}1.3589 * * * \\
(3.74)\end{array}$ & $\begin{array}{c}1.1752^{* * *} \\
(2.71)\end{array}$ & $\begin{array}{c}1.1968^{* * *} \\
(2.76)\end{array}$ & $\begin{array}{c}1.3223 * * \\
(2.28)\end{array}$ & $\begin{array}{c}1.1634^{*} \\
(1.68)\end{array}$ & $\begin{array}{c}1.2216^{*} \\
(1.77)\end{array}$ \\
\hline LIQ & $\begin{array}{c}0.0249^{*} \\
(1.84)\end{array}$ & $\begin{array}{c}0.0288^{* *} \\
(2.10)\end{array}$ & $\begin{array}{c}0.0334 * * \\
(2.33)\end{array}$ & $\begin{array}{c}0.0271 * * \\
(2.52)\end{array}$ & $\begin{array}{c}0.0290^{* * *} \\
(2.64)\end{array}$ & $\begin{array}{c}0.0315^{* * *} \\
(2.74)\end{array}$ & $\begin{array}{c}0.0155^{* *} \\
(2.07)\end{array}$ & $\begin{array}{c}0.0174 * * \\
(2.27)\end{array}$ & $\begin{array}{c}0.0141^{*} \\
(1.77)\end{array}$ & $\begin{array}{c}0.0167^{*} \\
(1.94)\end{array}$ & $\begin{array}{c}0.0190^{* *} \\
(2.17)\end{array}$ & $\begin{array}{c}0.0209 * * \\
(2.28)\end{array}$ & $\begin{array}{c}0.0160^{*} \\
(1.94)\end{array}$ & $\begin{array}{c}0.0220^{* * *} \\
(2.62)\end{array}$ & $\begin{array}{c}0.0233 * * * \\
(2.65)\end{array}$ & $\begin{array}{c}0.0358^{* * *} \\
(2.73)\end{array}$ & $\begin{array}{c}0.0393 * * * \\
(2.92)\end{array}$ & $\begin{array}{c}0.0423 * * * \\
(3.02)\end{array}$ \\
\hline VIX & $\begin{array}{c}0.0253 * * \\
(2.25)\end{array}$ & $\begin{array}{c}0.0108 \\
(0.93)\end{array}$ & $\begin{array}{c}0.0094 \\
(0.81)\end{array}$ & $\begin{array}{c}0.0086 \\
(0.96)\end{array}$ & $\begin{array}{c}0.0012 \\
(0.13)\end{array}$ & $\begin{array}{c}0.0004 \\
(0.04)\end{array}$ & $\begin{array}{c}0.0058 \\
(0.93)\end{array}$ & $\begin{array}{c}0.0003 \\
(0.05)\end{array}$ & $\begin{array}{c}0.0007 \\
(0.11)\end{array}$ & $\begin{array}{c}0.0368 * * * \\
(5.14)\end{array}$ & $\begin{array}{c}0.0288^{* * *} \\
(3.88)\end{array}$ & $\begin{array}{c}0.0281^{* * *} \\
(3.78)\end{array}$ & $\begin{array}{c}0.0034 \\
(0.49)\end{array}$ & $\begin{array}{c}0.0011 \\
(0.15)\end{array}$ & $\begin{array}{c}0.0007 \\
(0.09)\end{array}$ & $\begin{array}{c}0.0071 \\
(0.65)\end{array}$ & $\begin{array}{c}0.0003 \\
(0.03)\end{array}$ & $\begin{array}{r}-0.0007 \\
(-0.06)\end{array}$ \\
\hline CDS*LIQ & & $\begin{array}{c}27.2632 * * * \\
(3.50)\end{array}$ & $\begin{array}{c}33.3949 * * * \\
\quad(3.14)\end{array}$ & & $\begin{array}{c}13.9012^{* *} \\
(2.23)\end{array}$ & $\begin{array}{c}17.1267^{* *} \\
(2.01)\end{array}$ & & $\begin{array}{c}12.0069^{* *} \\
(2.76)\end{array}$ & $\begin{array}{c}3.4753 \\
(0.59)\end{array}$ & & $\begin{array}{c}15.4994 * * * \\
(3.12)\end{array}$ & $\begin{array}{c}16.8993 * * \\
(2.49)\end{array}$ & & $\begin{array}{c}18.0147^{* * *} \\
(3.78)\end{array}$ & $\begin{array}{c}20.5913^{* * *} \\
(3.16)\end{array}$ & & $\begin{array}{c}17.7274^{* *} \\
(2.32)\end{array}$ & $\begin{array}{c}23.3099 * * \\
(2.25)\end{array}$ \\
\hline CDS*VIX & & $\begin{array}{c}16.3438^{* *} \\
(2.28)\end{array}$ & $\begin{array}{c}15.1699 * * \\
(2.11)\end{array}$ & & $\begin{array}{c}6.0266 \\
(1.05)\end{array}$ & $\begin{array}{c}5.1820 \\
(0.90)\end{array}$ & & $\begin{array}{r}2.6157 \\
(0.65)\end{array}$ & $\begin{array}{c}2.3373 \\
(0.58)\end{array}$ & & $\begin{array}{c}7.7397^{*} \\
(1.69)\end{array}$ & $\begin{array}{c}7.1893 \\
(1.57)\end{array}$ & & $\begin{array}{c}4.9395 \\
(1.12)\end{array}$ & $\begin{array}{c}4.4323 \\
(1.01)\end{array}$ & & $\begin{array}{r}3.8137 \\
(0.54)\end{array}$ & $\begin{array}{c}2.3346 \\
(0.33)\end{array}$ \\
\hline LIQ*VIX & & $\begin{array}{c}0.5570^{* * * *} \\
(3.07)\end{array}$ & $\begin{array}{c}0.5076^{* * *} \\
(2.65)\end{array}$ & & $\begin{array}{c}0.3258^{* *} \\
(2.24)\end{array}$ & $\begin{array}{c}0.2930^{*} \\
(1.91)\end{array}$ & & $\begin{array}{c}0.2767 * * \\
(2.72)\end{array}$ & $\begin{array}{c}0.1746^{*} \\
(1.64)\end{array}$ & & $\begin{array}{c}0.3323^{* * *} \\
(2.87)\end{array}$ & $\begin{array}{c}0.2766^{* *} \\
(2.27)\end{array}$ & & $\begin{array}{c}-0.0254 \\
(-0.23)\end{array}$ & $\begin{array}{c}-0.0184 \\
(-0.16)\end{array}$ & & $\begin{array}{c}0.3110^{*} \\
(1.75)\end{array}$ & $\begin{array}{c}0.3132^{*} \\
(1.68)\end{array}$ \\
\hline MBS_CDS & & & $\begin{array}{c}-4,167.1340 \\
(-0.85)\end{array}$ & & & $\begin{array}{c}-2,175.5230 \\
(-0.56)\end{array}$ & & & $\begin{array}{c}5,607.1450^{* *} \\
(2.06)\end{array}$ & & & $\begin{array}{c}-1,035.6620 \\
(-0.33)\end{array}$ & & & $\begin{array}{c}-1,667.6480 \\
(-0.56)\end{array}$ & & & $\begin{array}{c}-3,589.9610 \\
(-0.75)\end{array}$ \\
\hline MBS_LIQ & & & $\begin{array}{c}1.2757^{* *} \\
(2.45)\end{array}$ & & & $\begin{array}{c}0.9881 * * \\
(2.37)\end{array}$ & & & $\begin{array}{c}0.6987 * * \\
(2.41)\end{array}$ & & & $\begin{array}{c}0.6235^{*} \\
(1.88)\end{array}$ & & & $\begin{array}{c}0.6042^{*} \\
(1.89)\end{array}$ & & & $\begin{array}{c}1.8372^{* * *} \\
(3.62)\end{array}$ \\
\hline MBS_VIX & & & $\begin{array}{c}0.5548 \\
(0.57)\end{array}$ & & & $\begin{array}{c}0.2590 \\
(0.33)\end{array}$ & & & $\begin{array}{c}0.9026^{*} \\
(1.67)\end{array}$ & & & $\begin{array}{c}0.7055 \\
(1.14)\end{array}$ & & & $\begin{array}{c}-0.2559 \\
(-0.43)\end{array}$ & & & $\begin{array}{r}-0.5827 \\
(-0.61)\end{array}$ \\
\hline Adj. $R^{2}$ & 0.9607 & 0.9619 & 0.9622 & 0.9819 & 0.9821 & 0.9823 & 0.9777 & 0.9781 & 0.9785 & 0.9609 & 0.9619 & 0.9621 & 0.9754 & 0.9759 & 0.9760 & 0.9559 & 0.9563 & 0.9570 \\
\hline PUR & $5.04 \%$ & $8.01 \%$ & $8.82 \%$ & $4.16 \%$ & $5.45 \%$ & $6.16 \%$ & $4.01 \%$ & $5.83 \%$ & $7.55 \%$ & $6.50 \%$ & $8.81 \%$ & $9.42 \%$ & $4.22 \%$ & $5.92 \%$ & $6.36 \%$ & $3.62 \%$ & $4.66 \%$ & $6.17 \%$ \\
\hline F-value & 938.19 & 850.26 & 763.48 & $2,081.12$ & $1,850.09$ & $1,658.66$ & $1,681.69$ & $1,503.77$ & $1,363.41$ & 944.18 & 849.72 & 761.32 & $1,524.55$ & $1,361.61$ & $1,217.13$ & 831.88 & 737.78 & 667.46 \\
\hline Obs. & 868 & 868 & 868 & 868 & 868 & 868 & 868 & 868 & 868 & 868 & 868 & 868 & 868 & 868 & 868 & 868 & 868 & 868 \\
\hline
\end{tabular}


Table IV: Regression Results for Dynamic Correlations vis-à-vis the US Stock Market (Daily Data) - Part C

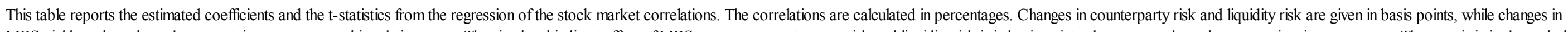

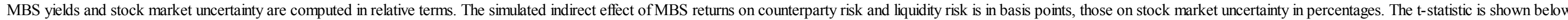

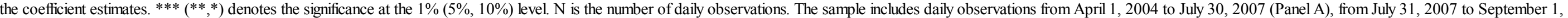
2009 (Panel B).

\section{Panel A: Pre-Crises Period}

\section{Regression}

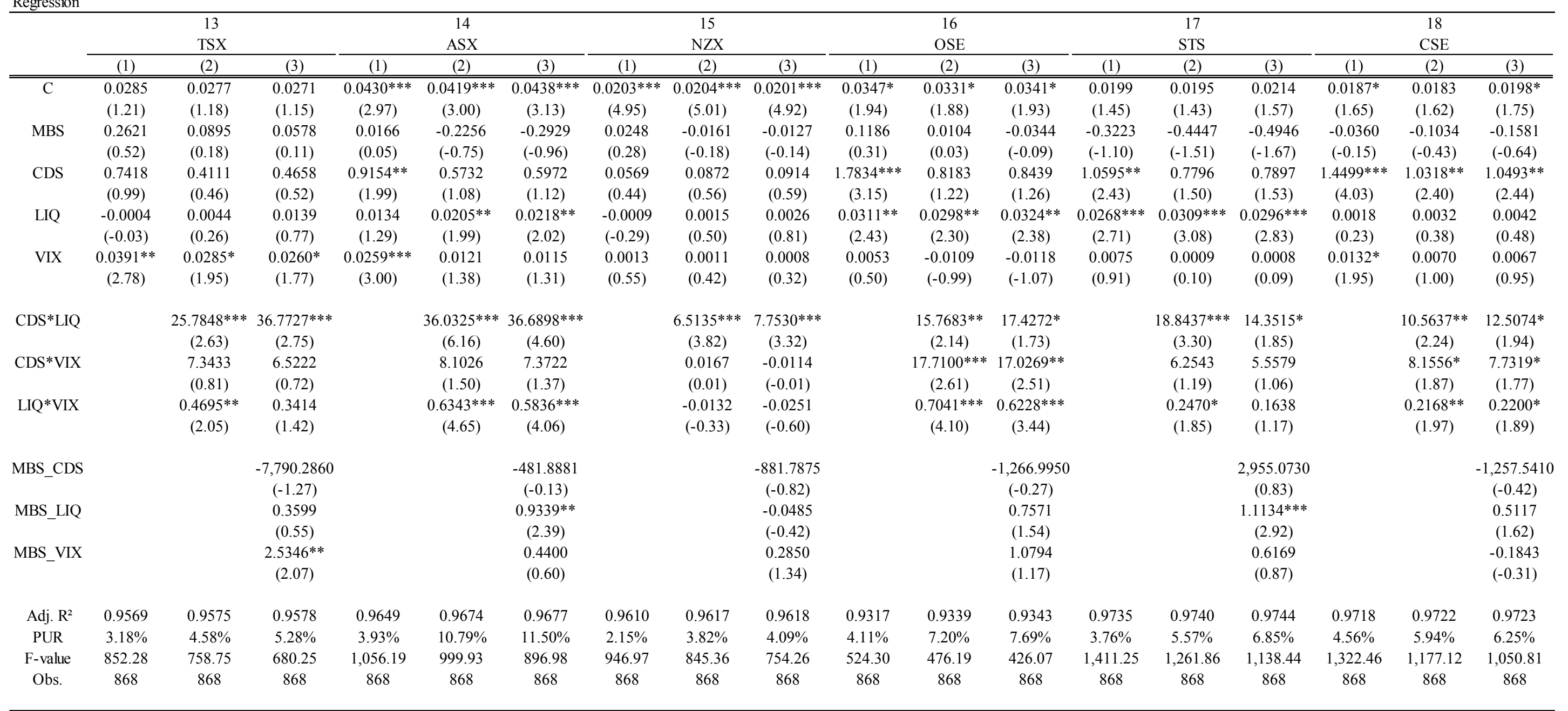


Table IV: Regression Results for Dynamic Correlations vis-à-vis the US Stock Market (Daily Data) - Part A

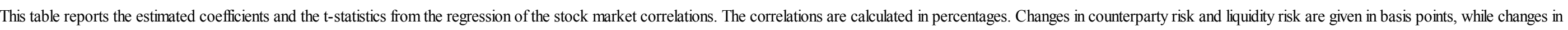

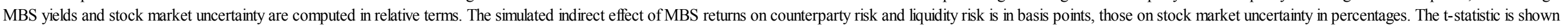

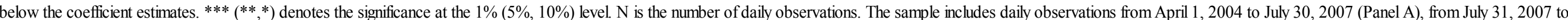
September 1, 2009 (Panel B).

Panel B: Crises Period

Regression

\begin{tabular}{|c|c|c|c|c|c|c|c|c|c|c|c|c|c|c|c|c|c|c|}
\hline \multicolumn{19}{|l|}{ Regression } \\
\hline & \multirow{2}{*}{\multicolumn{3}{|c|}{$\begin{array}{c}1 \\
\text { DAX }\end{array}$}} & \multirow{2}{*}{\multicolumn{3}{|c|}{$\begin{array}{c}2 \\
\text { CAC } \\
\end{array}$}} & \multirow{2}{*}{\multicolumn{3}{|c|}{$\begin{array}{c}3 \\
\text { MIB } \\
\end{array}$}} & \multirow{2}{*}{\multicolumn{3}{|c|}{$\begin{array}{c}4 \\
\text { AEX } \\
\end{array}$}} & \multirow{2}{*}{\multicolumn{3}{|c|}{$\begin{array}{c}5 \\
\text { POPSI } \\
\end{array}$}} & \multirow{2}{*}{\multicolumn{3}{|c|}{$\begin{array}{c}6 \\
\text { IBEX }\end{array}$}} \\
\hline & & & & & & & & & & & & & & & & & & \\
\hline & $(1)$ & (2) & (3) & $(1)$ & (2) & (3) & $(1)$ & $(2)$ & (3) & $(1)$ & $(2)$ & (3) & $(1)$ & (2) & (3) & $(1)$ & (2) & (3) \\
\hline $\mathrm{C}$ & $\begin{array}{c}0.0874 * * * \\
(2.95)\end{array}$ & $\begin{array}{c}0.0835^{* * *} \\
(2.89)\end{array}$ & $\begin{array}{c}0.0831^{* * * *} \\
(2.88)\end{array}$ & $\begin{array}{c}0.0889^{* * *} \\
(3.13)\end{array}$ & $\begin{array}{c}0.0833^{* * *} \\
(3.01)\end{array}$ & $\begin{array}{c}0.0830 * * * \\
(3.00)\end{array}$ & $\begin{array}{c}0.0549 * \\
(1.89)\end{array}$ & $\begin{array}{c}0.0482 * \\
(1.70)\end{array}$ & $\begin{array}{c}0.0469^{*} \\
(1.66)\end{array}$ & $\begin{array}{c}0.0977 * * * \\
(3.56)\end{array}$ & $\begin{array}{c}0.0890^{* * *} \\
(3.40)\end{array}$ & $\begin{array}{c}0.0922 * * * \\
(3.52)\end{array}$ & $\begin{array}{l}0.0364 \\
(1.07)\end{array}$ & $\begin{array}{c}0.0279 \\
(0.85)\end{array}$ & $\begin{array}{r}0.0257 \\
(0.78)\end{array}$ & $\begin{array}{c}0.0638^{* * *} \\
(2.57)\end{array}$ & $\begin{array}{c}0.0617^{* *} \\
(2.55)\end{array}$ & $\begin{array}{c}0.0609^{* *} \\
(2.52)\end{array}$ \\
\hline MBS & $\begin{array}{r}0.0737 \\
(0.41)\end{array}$ & $\begin{array}{c}0.0833 \\
(0.48)\end{array}$ & $\begin{array}{c}0.1018 \\
(0.59)\end{array}$ & $\begin{array}{c}0.1138 \\
(0.67)\end{array}$ & $\begin{array}{c}0.1158 \\
(0.70)\end{array}$ & $\begin{array}{c}0.1436 \\
(0.86)\end{array}$ & $\begin{array}{c}0.1369 \\
(0.78)\end{array}$ & $\begin{array}{c}0.1341 \\
(0.79)\end{array}$ & $\begin{array}{c}0.1511 \\
(0.89)\end{array}$ & $\begin{array}{c}0.0762 \\
(0.46)\end{array}$ & $\begin{array}{r}0.0759 \\
(0.48)\end{array}$ & $\begin{array}{c}0.1231 \\
(0.78)\end{array}$ & $\begin{array}{c}0.2500 \\
(1.23)\end{array}$ & $\begin{array}{c}0.2508 \\
(1.28)\end{array}$ & $\begin{array}{c}0.2550 \\
(1.29)\end{array}$ & $\begin{array}{c}0.1196 \\
(0.80)\end{array}$ & $\begin{array}{c}0.1279 \\
(0.88)\end{array}$ & $\begin{array}{c}0.1372 \\
(0.94)\end{array}$ \\
\hline CDS & $\begin{array}{c}0.0036 \\
(0.25)\end{array}$ & $\begin{array}{c}0.0056 \\
(0.41)\end{array}$ & $\begin{array}{c}0.0104 \\
(0.76)\end{array}$ & $\begin{array}{l}0.0037 \\
(0.27)\end{array}$ & $\begin{array}{l}0.0051 \\
(0.39)\end{array}$ & $\begin{array}{c}0.0103 \\
(0.77)\end{array}$ & $\begin{array}{c}0.0043 \\
(0.31)\end{array}$ & $\begin{array}{l}0.0054 \\
(0.40)\end{array}$ & $\begin{array}{c}0.0099 \\
(0.73)\end{array}$ & $\begin{array}{r}0.0077 \\
(0.59)\end{array}$ & $\begin{array}{c}0.0086 \\
(0.68)\end{array}$ & $\begin{array}{l}0.0127 \\
(1.01)\end{array}$ & $\begin{array}{c}-0.0012 \\
(-0.08)\end{array}$ & $\begin{array}{c}0.0003 \\
(0.02)\end{array}$ & $\begin{array}{c}0.0044 \\
(0.28)\end{array}$ & $\begin{array}{l}0.0100 \\
(0.84)\end{array}$ & $\begin{array}{l}0.0121 \\
(1.05)\end{array}$ & $\begin{array}{l}0.0157 \\
(1.36)\end{array}$ \\
\hline LIQ & $\begin{array}{c}0.0066 \\
(0.91)\end{array}$ & $\begin{array}{c}0.0067 \\
(0.95)\end{array}$ & $\begin{array}{c}0.0075 \\
(1.07)\end{array}$ & $\begin{array}{c}0.0060 \\
(0.86)\end{array}$ & $\begin{array}{c}0.0058 \\
(0.86)\end{array}$ & $\begin{array}{c}0.0067 \\
(0.99)\end{array}$ & $\begin{array}{c}0.0055 \\
(0.78)\end{array}$ & $\begin{array}{c}0.0052 \\
(0.75)\end{array}$ & $\begin{array}{c}0.0060 \\
(0.87)\end{array}$ & $\begin{array}{r}0.0057 \\
(0.85)\end{array}$ & $\begin{array}{c}0.0049 \\
(0.77)\end{array}$ & $\begin{array}{c}0.0054 \\
(0.85)\end{array}$ & $\begin{array}{c}-0.0034 \\
(-0.40)\end{array}$ & $\begin{array}{c}-0.0038 \\
(-0.48)\end{array}$ & $\begin{array}{r}-0.0030 \\
(-0.38)\end{array}$ & $\begin{array}{c}0.0053 \\
(0.88)\end{array}$ & $\begin{array}{c}0.0058 \\
(0.98)\end{array}$ & $\begin{array}{c}0.0064 \\
(1.10)\end{array}$ \\
\hline VIX & $\begin{array}{c}0.0185^{* *} \\
(2.32)\end{array}$ & $\begin{array}{l}0.0123 \\
(1.57)\end{array}$ & $\begin{array}{l}0.0107 \\
(1.35)\end{array}$ & $\begin{array}{c}0.0219 * * \\
(2.87)\end{array}$ & $\begin{array}{c}0.0153^{* *} \\
(2.03)\end{array}$ & $\begin{array}{c}0.0133^{*} \\
(1.76)\end{array}$ & $\begin{array}{c}0.0210^{* *} \\
(2.69)\end{array}$ & $\begin{array}{c}0.0138^{*} \\
(1.80)\end{array}$ & $\begin{array}{c}0.0119 \\
(1.54)\end{array}$ & $\begin{array}{c}0.0226^{* * *} \\
(3.07)\end{array}$ & $\begin{array}{c}0.0144 * * \\
(2.02)\end{array}$ & $\begin{array}{c}0.0136^{* *} \\
(1.90)\end{array}$ & $\begin{array}{c}0.0272^{* * *} \\
(2.98)\end{array}$ & $\begin{array}{c}0.0179 * * \\
(2.01)\end{array}$ & $\begin{array}{c}0.0160^{*} \\
(1.79)\end{array}$ & $\begin{array}{c}0.0082 \\
(1.23)\end{array}$ & $\begin{array}{c}0.0033 \\
(0.50)\end{array}$ & $\begin{array}{c}0.0019 \\
(0.29)\end{array}$ \\
\hline CDS*LIQ & & $\begin{array}{c}0.0016 \\
(0.03)\end{array}$ & $\begin{array}{r}0.0321 \\
(0.69)\end{array}$ & & $\begin{array}{c}0.0111 \\
(0.25)\end{array}$ & $\begin{array}{c}0.0402 \\
(0.90)\end{array}$ & & $\begin{array}{c}0.0134 \\
(0.30)\end{array}$ & $\begin{array}{c}0.0389 \\
(0.85)\end{array}$ & & $\begin{array}{c}0.0552 \\
(1.33)\end{array}$ & $\begin{array}{c}0.0783 \\
(1.85)\end{array}$ & & $\begin{array}{c}0.0306 \\
(0.59)\end{array}$ & $\begin{array}{c}0.0556 \\
(1.05)\end{array}$ & & $\begin{array}{c}-0.0292 \\
(-0.76)\end{array}$ & $\begin{array}{c}-0.0058 \\
(-0.15)\end{array}$ \\
\hline CDS*VIX & & $\begin{array}{c}0.4794 * * * \\
(3.93)\end{array}$ & $\begin{array}{c}0.4800^{* * *} \\
(3.79)\end{array}$ & & $\begin{array}{c}0.5334 * * * \\
(4.55)\end{array}$ & $\begin{array}{c}0.5163^{* * *} \\
(4.26)\end{array}$ & & $\begin{array}{c}0.5922^{* * * *} \\
(4.94)\end{array}$ & $\begin{array}{c}0.5813^{* * *} \\
(4.68)\end{array}$ & & $\begin{array}{c}0.6554^{* * *} \\
(5.92)\end{array}$ & $\begin{array}{c}0.6292 * * * \\
(5.48)\end{array}$ & & $\begin{array}{c}0.7469 * * * \\
(5.40)\end{array}$ & $\begin{array}{c}0.7501 * * * \\
\quad(5.22)\end{array}$ & & $\begin{array}{c}0.3915^{* * *} \\
(3.83)\end{array}$ & $\begin{array}{c}0.3952 * * * \\
(3.73)\end{array}$ \\
\hline LIQ*VIX & & $\begin{array}{c}0.0026 \\
(0.04)\end{array}$ & $\begin{array}{c}-0.0308 \\
(-0.46)\end{array}$ & & $\begin{array}{c}0.0532 \\
(0.84)\end{array}$ & $\begin{array}{c}0.0164 \\
(0.25)\end{array}$ & & $\begin{array}{r}0.0921 \\
(1.43)\end{array}$ & $\begin{array}{c}0.0576 \\
(0.87)\end{array}$ & & $\begin{array}{c}0.0524 \\
(0.88)\end{array}$ & $\begin{array}{c}0.0316 \\
(0.52)\end{array}$ & & $\begin{array}{c}0.0768 \\
(1.03)\end{array}$ & $\begin{array}{c}0.0438 \\
(0.57)\end{array}$ & & $\begin{array}{r}0.0227 \\
(0.41)\end{array}$ & $\begin{array}{c}-0.0039 \\
(-0.07)\end{array}$ \\
\hline MBS_CDS & & & $\begin{array}{c}9.3950^{* * *} \\
(2.75)\end{array}$ & & & $\begin{array}{c}9.4424 * * * \\
(2.88)\end{array}$ & & & $\begin{array}{c}7.9727 * * \\
(2.38)\end{array}$ & & & $\begin{array}{c}8.5668^{* * * *} \\
(2.76)\end{array}$ & & & $\begin{array}{c}7.2645^{*} \\
(1.87)\end{array}$ & & & $\begin{array}{c}6.9645^{* *} \\
(2.43)\end{array}$ \\
\hline MBS_LIQ & & & $\begin{array}{c}0.1370 \\
(1.32)\end{array}$ & & & $\begin{array}{c}0.1039 \\
(1.05)\end{array}$ & & & $\begin{array}{c}0.1310 \\
(1.29)\end{array}$ & & & $\begin{array}{c}-0.0557 \\
(-0.59)\end{array}$ & & & $\begin{array}{c}0.1799 \\
(1.53)\end{array}$ & & & $\begin{array}{l}0.1291 \\
(1.49)\end{array}$ \\
\hline MBS_VIX & & & $\begin{array}{c}0.1809 \\
(0.36)\end{array}$ & & & $\begin{array}{c}0.3888 \\
(0.81)\end{array}$ & & & $\begin{array}{c}0.3664 \\
(0.75)\end{array}$ & & & $\begin{array}{l}0.1921 \\
(0.42)\end{array}$ & & & $\begin{array}{l}0.2591 \\
(0.46)\end{array}$ & & & $\begin{array}{l}0.1427 \\
(0.34)\end{array}$ \\
\hline Adj. $R^{2}$ & 0.9848 & 0.9857 & 0.9858 & 0.9851 & 0.9860 & 0.9862 & 0.9856 & 0.9865 & 0.9866 & 0.9850 & 0.9864 & 0.9866 & 0.9870 & 0.9881 & 0.9881 & 0.9872 & 0.9879 & 0.9880 \\
\hline PUR & $0.93 \%$ & $6.75 \%$ & $7.82 \%$ & $1.69 \%$ & $7.58 \%$ & $8.77 \%$ & $1.48 \%$ & $7.51 \%$ & $8.31 \%$ & $1.98 \%$ & $11.40 \%$ & $12.32 \%$ & $1.73 \%$ & $9.68 \%$ & $10.16 \%$ & $0.23 \%$ & $5.91 \%$ & $6.78 \%$ \\
\hline F-value & $1,604.83$ & $1,501.79$ & $1,356.71$ & $1,639.74$ & $1,536.37$ & $1,389.96$ & $1,698.36$ & $1,593.49$ & $1,435.55$ & $1,625.97$ & $1,585.49$ & $1,430.68$ & $1,886.05$ & $1,807.75$ & $1,622.85$ & $1,912.27$ & $1,785.77$ & $1,609.51$ \\
\hline Obs. & 546 & 546 & 546 & 546 & 546 & 546 & 546 & 546 & 546 & 546 & 546 & 546 & 546 & 546 & 546 & 546 & 546 & 546 \\
\hline
\end{tabular}


Table IV: Regression Results for Dynamic Correlations vis-à-vis the US Stock Market (Daily Data) - Part B

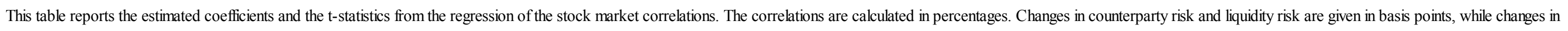

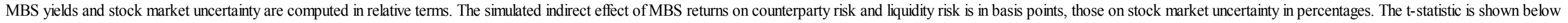

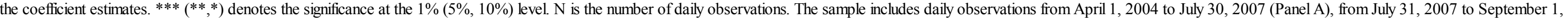
2009 (Panel B).

\section{Panel B: Crises Period}

\section{$\underline{\text { Regression }}$}

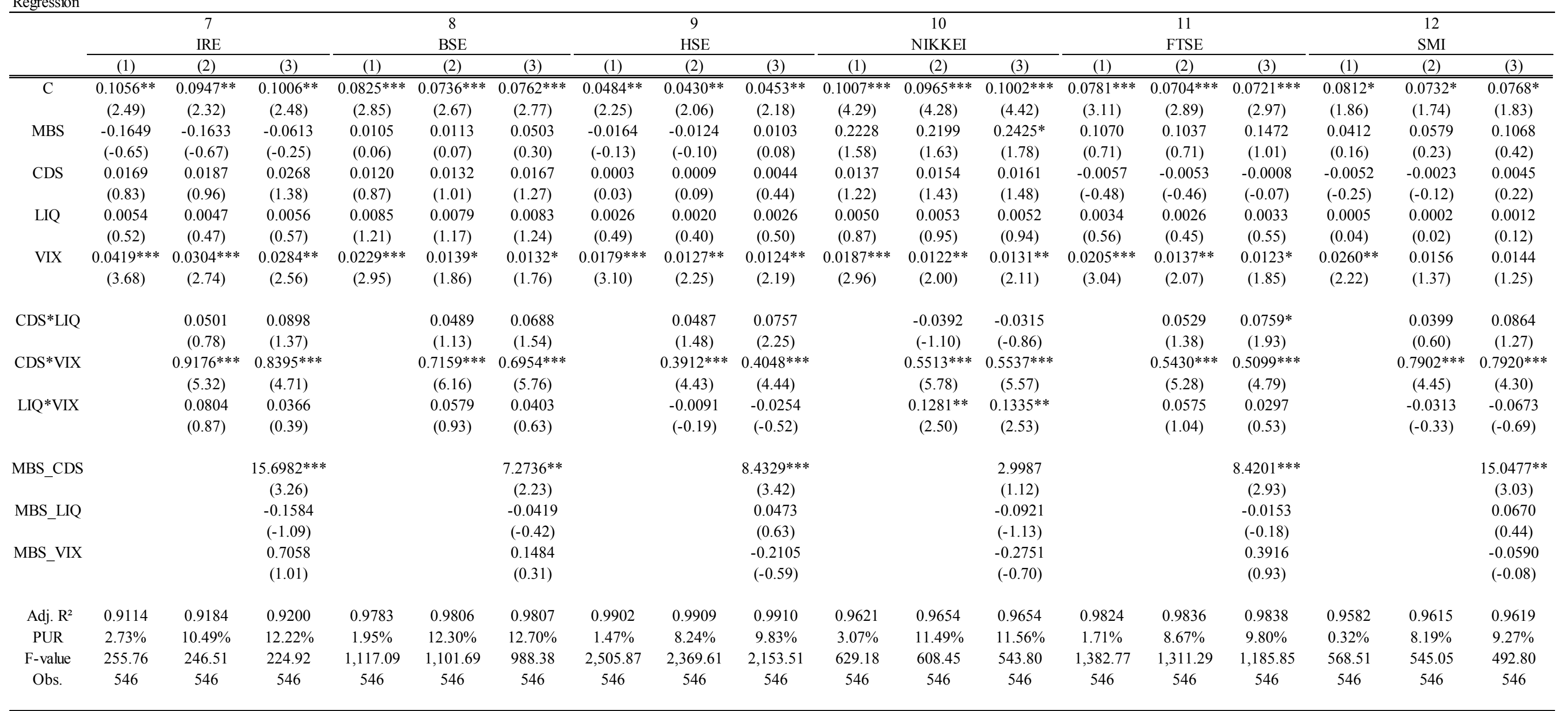


Table IV: Regression Results for Dynamic Correlations vis-à-vis the US Stock Market (Daily Data) - Part C

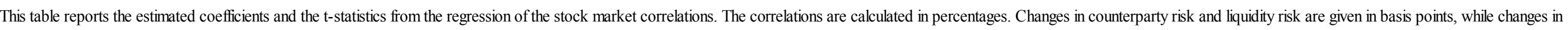

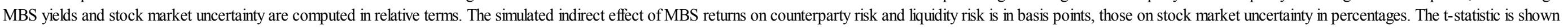

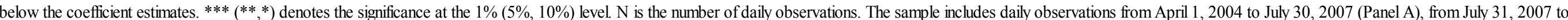
September 1, 2009 (Panel B).

Panel B: Crises Period

$\underline{\text { Regression }}$

\begin{tabular}{|c|c|c|c|c|c|c|c|c|c|c|c|c|c|c|c|c|c|c|}
\hline \multicolumn{19}{|l|}{ Regression } \\
\hline & \multirow{2}{*}{\multicolumn{3}{|c|}{$\begin{array}{c}13 \\
\text { TSX }\end{array}$}} & \multirow{2}{*}{\multicolumn{3}{|c|}{$\begin{array}{c}14 \\
\text { ASX }\end{array}$}} & \multirow{2}{*}{\multicolumn{3}{|c|}{$\begin{array}{c}15 \\
\mathrm{NZX}\end{array}$}} & \multirow{2}{*}{\multicolumn{3}{|c|}{$\begin{array}{c}16 \\
\text { OSE }\end{array}$}} & \multirow{2}{*}{\multicolumn{3}{|c|}{$\begin{array}{c}17 \\
\text { STS }\end{array}$}} & \multirow{2}{*}{\multicolumn{3}{|c|}{$\begin{array}{c}18 \\
\text { CSE }\end{array}$}} \\
\hline & & & & & & & & & & & & & & & & & & \\
\hline & $(1)$ & $(2)$ & (3) & (1) & (2) & (3) & (1) & $(2)$ & (3) & (1) & (2) & (3) & $(1)$ & (2) & (3) & (1) & (2) & (3) \\
\hline$\overline{\mathrm{C}}$ & $\begin{array}{c}0.0866^{* * *} \\
(1.99)\end{array}$ & $\begin{array}{c}0.0805^{* * *} \\
(1.85)\end{array}$ & $\begin{array}{c}0.0884 * * \\
(2.03)\end{array}$ & $\begin{array}{c}0.1692 * * * \\
(5.66)\end{array}$ & $\begin{array}{c}0.1686^{* * *} \\
(5.60)\end{array}$ & $\begin{array}{c}0.1764 * * * \\
(5.87)\end{array}$ & $\begin{array}{c}0.0610^{* * *} \\
(5.96)\end{array}$ & $\begin{array}{c}0.0628^{* *} \\
(6.18)\end{array}$ & $\begin{array}{c}0.0628^{* *} \\
(6.18)\end{array}$ & $\begin{array}{c}0.0582 \\
(1.42)\end{array}$ & $\begin{array}{c}0.0518 \\
(1.30)\end{array}$ & $\begin{array}{c}0.0563 \\
(1.41)\end{array}$ & $\begin{array}{c}0.0711 * * * \\
(2.66)\end{array}$ & $\begin{array}{c}0.0663 * * * \\
(2.57)\end{array}$ & $\begin{array}{c}0.0691 * * * \\
(2.68)\end{array}$ & $\begin{array}{c}0.0387 \\
(1.56)\end{array}$ & $\begin{array}{c}0.0366 \\
(1.53)\end{array}$ & $\begin{array}{c}0.0370 \\
(1.55)\end{array}$ \\
\hline MBS & $\begin{array}{c}-0.1260 \\
(-0.48)\end{array}$ & $\begin{array}{r}-0.1275 \\
(-0.49)\end{array}$ & $\begin{array}{c}-0.0756 \\
(-0.29)\end{array}$ & $\begin{array}{c}0.1500 \\
(0.83)\end{array}$ & $\begin{array}{c}0.1495 \\
(0.83)\end{array}$ & $\begin{array}{l}0.1977 \\
(1.09)\end{array}$ & $\begin{array}{c}0.0398 \\
(0.65)\end{array}$ & $\begin{array}{c}0.0420 \\
(0.69)\end{array}$ & $\begin{array}{c}0.0254 \\
(0.42)\end{array}$ & $\begin{array}{c}0.2328 \\
(0.94)\end{array}$ & $\begin{array}{c}0.2488 \\
(1.04)\end{array}$ & $\begin{array}{c}0.3008 \\
(1.25)\end{array}$ & $\begin{array}{r}0.0331 \\
(0.21)\end{array}$ & $\begin{array}{r}0.0416 \\
(0.27)\end{array}$ & $\begin{array}{r}0.0634 \\
(0.41)\end{array}$ & $\begin{array}{r}0.1175 \\
(0.79)\end{array}$ & $\begin{array}{c}0.1334 \\
(0.93)\end{array}$ & $\begin{array}{c}0.1542 \\
(1.07)\end{array}$ \\
\hline CDS & $\begin{array}{l}0.0313 \\
(1.50)\end{array}$ & $\begin{array}{l}0.0322 \\
(1.56)\end{array}$ & $\begin{array}{c}0.0335 \\
(1.60)\end{array}$ & $\begin{array}{l}-0.0135 \\
(-0.94)\end{array}$ & $\begin{array}{c}-0.0131 \\
(-0.91)\end{array}$ & $\begin{array}{r}-0.0141 \\
(-0.98)\end{array}$ & $\begin{array}{c}-0.0006 \\
(-0.12)\end{array}$ & $\begin{array}{r}-0.0007 \\
(-0.14)\end{array}$ & $\begin{array}{c}-0.0023 \\
(-0.47)\end{array}$ & $\begin{array}{c}0.0150 \\
(0.76)\end{array}$ & $\begin{array}{c}0.0177 \\
(0.93)\end{array}$ & $\begin{array}{c}0.0212 \\
(1.10)\end{array}$ & $\begin{array}{r}0.0107 \\
(0.83)\end{array}$ & $\begin{array}{c}0.0125 \\
(1.01)\end{array}$ & $\begin{array}{c}0.0162 \\
(1.31)\end{array}$ & $\begin{array}{c}-0.0095 \\
(-0.79)\end{array}$ & $\begin{array}{r}-0.0069 \\
(-0.60)\end{array}$ & $\begin{array}{r}-0.0027 \\
(-0.24)\end{array}$ \\
\hline LIQ & $\begin{array}{c}0.0075 \\
(0.71)\end{array}$ & $\begin{array}{c}0.0071 \\
(0.67)\end{array}$ & $\begin{array}{c}0.0070 \\
(0.66)\end{array}$ & $\begin{array}{l}0.0017 \\
(0.23)\end{array}$ & $\begin{array}{c}0.0018 \\
(0.24)\end{array}$ & $\begin{array}{c}0.0012 \\
(0.17)\end{array}$ & $\begin{array}{c}0.0015 \\
(0.60)\end{array}$ & $\begin{array}{c}0.0016 \\
(0.65)\end{array}$ & $\begin{array}{c}0.0014 \\
(0.56)\end{array}$ & $\begin{array}{c}-0.0012 \\
(-0.12)\end{array}$ & $\begin{array}{c}-0.0013 \\
(-0.14)\end{array}$ & $\begin{array}{c}-0.0010 \\
(-0.10)\end{array}$ & $\begin{array}{c}0.0058 \\
(0.89)\end{array}$ & $\begin{array}{c}0.0058 \\
(0.91)\end{array}$ & $\begin{array}{c}0.0063 \\
(1.01)\end{array}$ & $\begin{array}{c}-0.0041 \\
(-0.68)\end{array}$ & $\begin{array}{c}-0.0037 \\
(-0.64)\end{array}$ & $\begin{array}{c}-0.0030 \\
(-0.52)\end{array}$ \\
\hline VIX & $\begin{array}{c}0.0416^{* * *} \\
\quad(3.55)\end{array}$ & $\begin{array}{c}0.0351 * * \\
(2.98)\end{array}$ & $\begin{array}{c}0.0368^{* * *} \\
(3.09)\end{array}$ & $\begin{array}{c}0.0110 \\
(1.37)\end{array}$ & $\begin{array}{c}0.0098 \\
(1.20)\end{array}$ & $\begin{array}{c}0.0120 \\
(1.46)\end{array}$ & $\begin{array}{l}-0.0032 \\
(-1.16)\end{array}$ & $\begin{array}{l}-0.0015 \\
(-0.53)\end{array}$ & $\begin{array}{c}-0.0006 \\
(-0.22)\end{array}$ & $\begin{array}{c}0.0216^{* *} \\
(1.96)\end{array}$ & $\begin{array}{l}0.0127 \\
(1.17)\end{array}$ & $\begin{array}{l}0.0125 \\
(1.14)\end{array}$ & $\begin{array}{c}0.0154 * * \\
(2.13)\end{array}$ & $\begin{array}{c}0.0088 \\
(1.26)\end{array}$ & $\begin{array}{l}0.0086 \\
(1.22)\end{array}$ & $\begin{array}{c}0.0250^{* * *} \\
\quad(3.74)\end{array}$ & $\begin{array}{c}0.0197 * * \\
(3.03)\end{array}$ & $\begin{array}{c}0.0184 * * \\
(2.82)\end{array}$ \\
\hline CDS*LIQ & & $\begin{array}{c}0.0211 \\
(0.31)\end{array}$ & $\begin{array}{c}0.0342 \\
(0.49)\end{array}$ & & $\begin{array}{c}-0.0109 \\
(-0.23)\end{array}$ & $\begin{array}{r}-0.0151 \\
(-0.31)\end{array}$ & & $\begin{array}{c}-0.0044 \\
(-0.28)\end{array}$ & $\begin{array}{c}-0.0093 \\
(-0.56)\end{array}$ & & $\begin{array}{c}0.0300 \\
(0.48)\end{array}$ & $\begin{array}{c}0.0504 \\
(0.78)\end{array}$ & & $\begin{array}{r}0.0131 \\
(0.32)\end{array}$ & $\begin{array}{c}0.0436 \\
(1.05)\end{array}$ & & $\begin{array}{r}-0.0127 \\
(-0.34)\end{array}$ & $\begin{array}{c}0.0140 \\
(0.36)\end{array}$ \\
\hline CDS*VIX & & $\begin{array}{c}0.5263^{* * *} \\
(2.87)\end{array}$ & $\begin{array}{c}0.5224 * * * \\
(2.74)\end{array}$ & & $\begin{array}{c}0.1025 \\
(0.81)\end{array}$ & $\begin{array}{c}0.0833 \\
(0.63)\end{array}$ & & $\begin{array}{c}-0.1456 * * * \\
(-3.39)\end{array}$ & $\begin{array}{c}-0.1216^{* * *} \\
(-2.73)\end{array}$ & & $\begin{array}{c}0.6685^{* * * *} \\
(3.97)\end{array}$ & $\begin{array}{c}0.6425 * * * \\
(3.66)\end{array}$ & & $\begin{array}{c}0.5063^{* * * *} \\
(4.63)\end{array}$ & $\begin{array}{c}0.5287^{* * * *} \\
(4.67)\end{array}$ & & $\begin{array}{c}0.3937 * * * \\
(3.89)\end{array}$ & $\begin{array}{c}0.3920 * * * \\
(3.74)\end{array}$ \\
\hline LIQ*VIX & & $\begin{array}{r}0.0687 \\
(0.70)\end{array}$ & $\begin{array}{c}0.0815 \\
(0.80)\end{array}$ & & $\begin{array}{l}0.0261 \\
(0.38)\end{array}$ & $\begin{array}{c}0.0524 \\
(0.75)\end{array}$ & & $\begin{array}{c}-0.0321 \\
(-1.39)\end{array}$ & $\begin{array}{c}-0.0198 \\
(-0.84)\end{array}$ & & $\begin{array}{c}-0.0358 \\
(-0.39)\end{array}$ & $\begin{array}{c}-0.0491 \\
(-0.53)\end{array}$ & & $\begin{array}{c}0.0047 \\
(0.08)\end{array}$ & $\begin{array}{r}-0.0117 \\
(-0.19)\end{array}$ & & $\begin{array}{c}-0.0410 \\
(-0.75)\end{array}$ & $\begin{array}{c}-0.0685 \\
(-1.23)\end{array}$ \\
\hline MBS_CDS & & & $\begin{array}{c}5.7104 \\
(1.11)\end{array}$ & & & $\begin{array}{c}0.7400 \\
(0.21)\end{array}$ & & & $\begin{array}{c}-2.1844^{* *} \\
(-1.81)\end{array}$ & & & $\begin{array}{c}7.9489^{*} \\
(1.68)\end{array}$ & & & $\begin{array}{c}9.3407 * * * \\
(3.06)\end{array}$ & & & $\begin{array}{c}8.3945 * * * \\
(2.96)\end{array}$ \\
\hline MBS_LIQ & & & $\begin{array}{c}-0.2271 \\
(-1.46)\end{array}$ & & & $\begin{array}{c}-0.3151^{* *} \\
(-2.93)\end{array}$ & & & $\begin{array}{c}0.0130 \\
(0.36)\end{array}$ & & & $\begin{array}{c}-0.1119 \\
(-0.78)\end{array}$ & & & $\begin{array}{c}0.0630 \\
(0.68)\end{array}$ & & & $\begin{array}{c}0.0934 \\
(1.09)\end{array}$ \\
\hline MBS_VIX & & & $\begin{array}{c}-0.5024 \\
(-0.67)\end{array}$ & & & $\begin{array}{c}-0.3958 \\
(-0.76)\end{array}$ & & & $\begin{array}{c}-0.3263^{*} \\
(-1.86)\end{array}$ & & & $\begin{array}{c}0.0728 \\
(0.11)\end{array}$ & & & $\begin{array}{c}-0.3255 \\
(-0.73)\end{array}$ & & & $\begin{array}{c}0.1324 \\
(0.32)\end{array}$ \\
\hline Adj. $R^{2}$ & 0.9777 & 0.9781 & 0.9781 & 0.9443 & 0.9441 & 0.9448 & 0.9529 & 0.9539 & 0.9542 & 0.9862 & 0.9871 & 0.9871 & 0.9880 & 0.9889 & 0.9891 & 0.9798 & 0.9814 & 0.9816 \\
\hline PUR & $3.25 \%$ & $5.05 \%$ & $5.28 \%$ & $0.17 \%$ & $-0.20 \%$ & $1.09 \%$ & $-0.22 \%$ & $2.00 \%$ & $2.72 \%$ & $0.96 \%$ & $7.46 \%$ & $7.58 \%$ & $0.83 \%$ & $8.57 \%$ & $9.79 \%$ & $2.24 \%$ & $10.11 \%$ & $11.25 \%$ \\
\hline F-value & $1,085.19$ & 973.58 & 871.52 & 421.27 & 369.40 & 334.46 & 501.72 & 452.10 & 406.90 & $1,772.63$ & $1,671.14$ & $1,494.08$ & $2,037.48$ & $1,946.73$ & $1,762.04$ & $1,201.11$ & $1,151.53$ & $1,041.68$ \\
\hline Obs. & 546 & 546 & 546 & 546 & 546 & 546 & 546 & 546 & 546 & 546 & 546 & 546 & 546 & 546 & 546 & 546 & 546 & 546 \\
\hline
\end{tabular}

